\title{
O PERFIL DO PODER LEGISLATIVO DA CAPITAL E DO ESTADO DE MATO GROSSO (1983-2004)
}

\begin{abstract}
Alair Silveira
RESUMO

O artigo é o produto de uma pesquisa realizada nas duas principais casas legislativas do Estado: a Assembléia Legislativa (ALMT) e a Câmara Municipal de Cuiabá (CMC). Ao todo, foram pesquisados 20 anos na ALMT e $22 \mathrm{na} C M C$, totalizando cinco legislaturas em cada uma das casas, a partir de 1983. Reflete sobre o perfil dos parlamentos mato-grossense e cuiabano a partir da composição partidária, das profissóes de origem e das experiências com organizações coletivas, entre outros; identificando a enorme capacidade de perpetuação no poder por parte dos parlamentares, seja por meio do processo eleitoral, seja por meio da direção de empresas estatais. Valendo-nos especialmente de Claus Offe e Max Weber, confrontamos tanto o pressuposto de Offe, segundo o qual os empresários valem-se das estruturas de poder para promover a valorização do capital, quanto o weberiano, segundo o qual os políticos vocacionais são aqueles que vivem para a politica e, portanto, têm recursos materiais que lhes garantem independência, diferentemente daqueles que vivem da política, ou seja, da qual dependem para a própria sobrevivência. A análise dos dados da pesquisa efetuada permitiu-me identificar fortes elementos que corroboram o primeiro pressuposto, mas põe em xeque a validade do segundo. Ao consolidar os meios de manter-se no arranjo institucional, seja via reeleição, pela disputa por outros cargos eletivos seja, ainda, via exercicio de direção de secretarias elou demais órgãos públicos, esses parlamentares também vão tecendo os instrumentos legislativos que garantem a preservação e a ampliação de seus interesses particulares e de classe; como, aliás, bem identificou Claus Offe. Assim, ao passar a viverem para a politica tais politicos passam, também, a viver da política.
\end{abstract}

PALAVRAS-CHAVE: Poder Legislativo; partidos políticos; poder; renovação política; recondução política.

\section{INTRODUÇÃO}

Este artigo é resultado de uma extensa - e intensa - pesquisa realizada em duas esferas legislativas de Mato Grosso: a Assembléia Legislativa Estadual e a Câmara Municipal de Cuiabá. Prevista inicialmente com um corte histórico compreendido entre 1985 (a redemocratização brasileira) e 2002, essa pesquisa acabou retrocedendo a $1983^{1}$ e avançando sobre os anos de 2003 e 2004, de forma a contemplar a integralidade das legislaturas estudadas.

Em um ambiente institucional marcado pela falta de tradição com pesquisas científicas, especialmente aquelas que adentram as relações de poder político, muitas foram as dificuldades para o desenvolvimento desse trabalho. Especialmen-

\footnotetext{
1 Nessas duas décadas foram sete os presidentes que estiveram à frente do Governo Federal: João Figueiredo (19811985); José Sarney (1985-1989); Fernando Collor de Mello (1990-1992); Itamar Franco (1992-1994); Fernando Henrique Cardoso (1995-1998 e 1999-2002) e Luís Inácio Lula da Silva (2003-2006).
}

te, além da desconfiança habitual e dos obstáculos gratuitamente interpostos, há, efetivamente, uma enorme carência de dados disponíveis. Apesar disso, ao longo de um exaustivo processo de garimpagem, foi possível identificar o perfil do poder Legislativo estadual e o de Cuiabá.

Poder de extraordinário poder, e que detém a prerrogativa de elaboração das leis que fundam o Estado de Direito, o poder Legislativo é um importante espaço para promoção pessoal na disputa por cargos eletivos na medida em que, paradoxalmente, a relativa invisibilidade social quanto ao acompanhamento individual da atuação parlamentar tanto o promove quanto o protege. Dessa forma, essa pesquisa buscou identificar, fundamentalmente, o perfil desses políticos que se mantêm ao longo dos anos à frente do poder, tendo como referência a reflexão feita por Claus Offe quanto à dupla seletividade do Estado.

Nesse sentido, confirmou-se a principal hipótese que norteou esse trabalho: o empresariado (urbano ou rural) tem presença expressiva no poder Legislativo - especialmente na Assembléia

Rev. Sociol. Polít., Curitiba, v. 17, n. 34, p. 271-299, out. 2009 271 
Legislativa -, o que contradiz a máxima de Weber (1968), segundo a qual aqueles que dispõem de recursos materiais podem viver para a política e não $d a$ política. O que se observa é que $a$ política passa a ser o investimento pessoal de médio e longo prazo, por meio do qual o empresário vai alçando novos vôos políticos (ou mesmo mantendo os espaços institucionais conquistados), o que lhe permite delegar a terceiros o exercício cotidiano da administração dos negócios privados, aparentemente priorizando a política de interesse coletivo. Entretanto, como a lógica do interesse privadoempresarial não é a lógica do interesse público, é possível extrair-se daí que o exercício da política institucional não se contrapõe ao interesse privado, na medida em que se constitui em um caminho de convergência em que o espaço estatal converte-se, como diz Offe, em um importante instrumento de valorização do capital.

\section{PODER LEGISLATIVO: SINGULARIDADE E POTENCIALIDADES}

O poder Legislativo é considerado um poder singular. Por um lado, expressa a multiplicidade das manifestações políticas da sociedade na medida em que é composto pela proporcionalidade eleitoral da vontade coletiva; por outro, tem como principal atribuição a elaboração de leis a partir das quais o poder Executivo executa ${ }^{2}$ e o poder Judiciário julga.

Se o surgimento do Estado representa a criação de um poder comum, sob o qual todos os homens $^{3}$ estão organizados e submetidos, seu poder ascendente e "irresistivel"4 funda-se no mo-

2 A correta crítica quanto ao excesso de Medidas Provisórias (MPs) enviadas pelo poder Executivo (banalizando a autorização prevista constitucionalmente para situações específicas e emergenciais), deve ser considerada sob o princípio da separação dos poderes, segundo o qual a prerrogativa de elaboração das leis é do poder Legislativo. Dessa forma, a conivência do poder Legislativo responde por uma dupla responsabilidade: 1) tolera os inadmissíveis excessos, submetendo-se à dinâmica das "prioridades" estabelecidas pelo poder Executivo e 2) não cumpre seu poder fiscalizador (contrapeso) sobre o Executivo, exigindo-lhe o respeito às leis constituídas.

3 Trata-se do gênero humano e, nesse sentido, doravante, sempre que referir-me aos "homens", "trabalhadores" ou "indivíduos" estou considerando sujeitos históricos e, portanto, ambos os sexos.

4 Trata-se do poder de imperium, inerente à natureza do próprio Estado. Ressalve-se aqui que esse poder, por mais nopólio - consentido - das leis e da força. Conseqüentemente, a exclusividade para a elaboração, o julgamento e a execução legislativa está distribuída pelos poderes que constituem o próprio Estado. Assim, a definição das competências e o estabelecimento dos contrapesos 5 entre o poder Executivo, o Legislativo e o Judiciário é imprescindível para dar unidade ao próprio Estado.

Dessa forma, em que pese o fato de que cabe ao poder Legislativo a elaboração e a fiscalização das leis (particularmente aquelas de responsabilidade do Executivo), nossa cultura eleitoral é marcada pela preponderância do poder Executivo. No que concerne ao Legislativo, ao contrário, há um profundo desconhecimento, desinteresse e desatenção quanto às atribuições $\mathrm{e}$, portanto, $\mathrm{o}$ poder que esse poder detém. Desse ostracismo os parlamentares retiram parte do seu poder de manutenção e auto-preservação política.

Se podemos creditar à nossa história política latino-americana a centralidade dos papéis executivos, firmados sob o império dos coronéis ${ }^{6} \mathrm{e}$ dos governadores, o poder Executivo tem como contra-face a maior visibilidade pública e, conseqüentemente, maior reconhecimento social. Dessa forma, tanto para os créditos de políticas socialmente populares quanto para o descrédito de políticas impopulares ou mesmo antipopulares, os titulares desse poder estão em evidência no cenário político eleitoral. E mesmo considerando-se a frágil memória política ${ }^{7}$ que marca o comportamento eleitoral brasileiro, aqueles que exercem o poder Executivo detêm maior raio de abrangência e perma-

"irresistível” que possa ser, não pode prescindir - por muito tempo - de legitimidade social, o que recoloca o poder originário nas mãos dos próprios homens.

5 O contrapeso consiste em um mecanismo para equilíbrio entre os poderes, de forma a assegurar que nenhum deles detenha mais poder do que o outro. Esse recurso, articulado à distribuição das competências, representam os instrumentos normativos para garantir relações harmônicas, equilibradas e independentes. Dessa forma, as leis representam o fio condutor dessa normatividade, conforme bem ensinou Montesquieu.

6 Utilizo essa definição no sentido lato: tanto em referência àqueles que se valeram do poder de cooptação e submissão política a partir do poder econômico, quanto àqueles que exerceram o poder estatal em razão do poder das armas (independente da patente e do período histórico).

7 Dediquei-me a essa análise no livro Memória Social \& Processo Eleitoral - As motivações do voto em Cuiabá e Várzea Grande. Cf. Silveira (2002). 
nência na memória dos eleitores, posto que são acompanhados com mais atenção pelos Meios de Comunicação de Massa (MCM). Além disso, o imaginário social credita ao poder Executivo todo o poder decisório sobre as políticas que envolvem a vida cotidiana.

Nesse universo de percepção política por parte do eleitorado, os parlamentares mantêm-se sobre o véu protetor da invisibilidade pública. Protegidos pelo anonimato das votações coletivas e pela falta de acompanhamento e fiscalização tanto da imprensa quanto dos cidadãos, os parlamentares somente saem do ostracismo mais efetivo quando são autores de projetos polêmicos ou, mais corriqueiramente, quando estão envolvidos em denúncias de ilegalidades de toda natureza: corrupção, nepotismo, formação de quadrilha, peculato e tantas outras formatações jurídicas.

Sob a forma de um corpo, as posições políticas materializadas em acordos e votações são diluídas no conjunto, sobressaindo-se como elemento de informação apenas os resultados finais das deliberações. Nesse processo de cobertura e acompanhamento midiático e social, tanto as posições mais conseqüentes com os discursos pré-eleitorais e o compromisso social ficam comprometidos, quanto servem para proteger aqueles que traem suas promessas e revelam seus reais (e inconfessáveis) compromissos. Ao final, é o poder Legislativo como um todo que recebe os louros ou o descrédito e a desconfiança social.

Tem-se, assim, que o processo eleitoral que explora o personalismo, o carisma e o histórico pessoal do candidato promove o eclipse - racional e pragmático ${ }^{8}$ - do projeto político e social que norteia o programa do partido. Submetido à ordem do anonimato ou à lógica da "governabilidade", o

${ }^{8}$ A atualidade e relevância dos partidos políticos (questionada por algumas correntes teóricas) é inegável, posto que a aparência jamais deve ser tomada como a explicação da essência das coisas. A aparente irrelevância dos partidos, quando observadas as campanhas eleitorais e o trocatroca partidário, por exemplo, toma como fato aquilo que é um recurso (não propriamente novo, porém, aprofundado) de isolar o candidato do partido de forma a proteger do conhecimento social o verdadeiro projeto de sociedade comungado pelo partido. Esse recurso sempre permitiu que os homens, quando desgastados politicamente, pudessem ser retirados temporariamente de cena, preservando o próprio projeto (que é, na verdade, o grande elemento definidor das disputas e do exercício do poder institucional). $\mathrm{Na}$ projeto descola-se - aparentemente - dos políticos. Nessa "nova" ordem, o recurso ao personalismo é utilizado, também, como forma de tradução ${ }^{9}$ ou de controle social mais efetivo.

No poder Legislativo, por sua vez, esse recurso não tem relevância para consumo interno, porém, mantém sua força como recurso para consumo externo. Sua efetividade assenta-se no equilíbrio entre a proteção do anonimato das deliberações e o discurso público de arauto das mais nobres políticas e práticas. Sem a contraposição dos fatos, o discurso assume a forma de verdade fática.

Explorando a cultura nacional ${ }^{10}$, firmada sobre a emotividade típica do brasileiro, o recurso à 'vitimação' é uma prática usual para a isenção das responsabilidades públicas quando os fatos desmentem os discursos. A capacidade de solidariedade social para com a pseudo-vítima (cuja responsabilidade parece restituir-se à ignorância dos fatos que "também" condena e ao excesso de confiança nos "verdadeiros" culpados) é surpreendente. Por outro lado, as condições objetivas contribuem para um pragmatismo eleitoral destituído da mesma moral que orienta a vida privada. Seja pela experiência concreta com uma política de mercado eleitoral, seja pela absoluta carência

mesma perspectiva, a troca de partido não representa, necessariamente, troca de projeto de sociedade. Na maioria dos casos, trata-se de um ajuste de interesses pessoais ou de grupo, sem nenhuma referência ao projeto partidário, posto que vários partidos podem defender o mesmo projeto (e efetivamente o fazem).

9 Esse processo de tradução popular maniqueísta das políticas mais complexas é prática corrente do Populismo e do Neopopulismo. Vários políticos populistas de envergadura histórica foram exímios tradutores (simplificadores) da macropolítica. Lula é um exemplar desse time de "tradutores" que, de forma contumaz, reduz a política ao pragmatismo dos interesses no poder, negando princípios partidários e condenando as diferenças ideológicas a " $b r a$ vatas" de oposição.

10 Sérgio Buarque de Hollanda, em Raízes do Brasil; Gilberto Freire, em Casa Grande e Senzala e Roberto DaMatta, em Carnaval, Malandros e Heróis, são alguns dos clássicos que trabalham a cultura do homem brasileiro: cordial, socialmente pautado pela rigidez hierárquica, orientado pelo jeitinho e pelas relações pessoalizadas e fortemente emotivas. Em outra perspectiva, podemos remeter a Nicolau Maquiavel, que ensina que os governantes, quando implementam políticas impopulares ou socialmente condenáveis, devem imputar a responsabilidade pelas mesmas aos seus assessores, reservando para si aquelas políticas que alcançam prestígio social. 
em que vivem milhões de pessoas. Para tanto, boa parte do eleitorado desenvolve uma dupla moralidade: a da esfera política e a da vida social. A primeira é associada à amoralidade ${ }^{11}$, a segunda à moralidade pautada pela honestidade pessoal e pela solidariedade social. Conseqüentemente, a lógica prevalecente no campo da política eleitoral é a maximização dos resultados também por parte do eleitor, que desenvolverá uma espécie de tolerância para com a amoralidade, desde que produza algum tipo de resultado objetivo para sua vida ou, em último caso, produza a diferença entre tantos considerados iguais (isto é, movidos pela mesma amoralidade).

Nessa perspectiva, os parlamentares desfrutam de condições objetivamente mais favoráveis. Porém, contraditoriamente, reside aí sua força e também sua fragilidade. Se a falta de visibilidade durante o mandato permite-lhes preservarem-se de responder pelas políticas que ajudam a implementar, por outro lado, essa mesma invisibilidade pode condená-los à derrota eleitoral. Não por acaso, muitos fazem do recurso econômico e das emendas orçamentárias o diferencial no processo eleitoral.

\section{AS RELAÇÕES TRIANGULARES DE PO- DER}

Claus Offe (1984), ao analisar as formas por meio das quais o Estado realiza a valorização do capital, identificou mais do que a dupla seletividade que protege a totalidade dos interesses do capital frente aos interesses míopes dos capitalistas e daqueles genericamente denominados anti-capitalistas. Offe identificou que esse instrumento (a dupla seletividade), para assegurar a preservação e a realização dos interesses do capital, somente pode gozar de efetividade e, portanto, legitimidade ${ }^{12}$ social, se conseguir "convencer" o conjunto da sociedade civil de que os interesses particulares que realiza são interesses públicos. Para poder cumprir essa difícil exigência, o Estado vale-se do que Offe denomina de "filtros".

\footnotetext{
11 Desenvolvi esse argumento no livro Memória Social \& Processo Eleitoral (SILVEIRA, 2002).

12 O conceito de legitimidade utilizado é o desenvolvido por Max Weber, de acordo com o qual a legitimidade somente pode ser conferida por aquele(s) que está(ão) na condição subalterna de determinada relação, considerandoa "justa".
}

Os filtros (identificados como sócio-estruturais, ideológicos, processuais e repressivos ${ }^{13}$ ) são imprescindíveis para o êxito da política de convencimento cotidiano. Assim, articulada com as contribuições dos autores da teoria da influência e dos fatores limitativos, a tese de Claus Offe é fundamental para compreendermos o perfil dos parlamentares de Mato Grosso no período estudado.

Dizem, os teóricos da influência ${ }^{14}$, que os capitalistas beneficiam-se de várias condições privilegiadas para fazer valer seus interesses: utilizam grupos de interesse para fazer demandas ao Estado; valem-se dos meios de comunicação de massa para promover, cotidianamente, o disciplinamento ideológico da sociedade; ameaçam com "greves de investimentos" 15 como forma de forçar a concessão de benefícios fiscais e financeiros; financiam campanhas eleitorais de empresários ou candidatos comprometidos com os princípios do capitalismo e que gozem de viabilidade eleitoral e, por fim, participam diretamente, ou por meio de seus prepostos, do processo decisório do Estado, na condição de ministros e secretários, travestidos como portadores de conhecimento e interesse técnico, isentos de interesse político e corte classista.

A convergência desse conjunto de recursos por parte do empresariado com os instrumentos estruturais do próprio Estado, segundo Offe, permite a realização da valorização do capital de forma relativamente tranqüila. Essa estabilidade política e social é tanto mais efetiva quanto maior for

13 O filtro repressivo somente é utilizado (especialmente no caso de países desenvolvidos) como último recurso. Isto é, quando todos os demais foram ineficientes e/ou insuficientes para construir as condições de aceitação social exigida para a tranqüila realização da valorização do capital em condições de estabilidade social e política.

14 Os chamados teóricos da influência (também conhecidos como "elitistas") defendem que os capitalistas (isolados ou em grupo) articulam seus interesses sobre o Estado, pressionando-o para atender seus interesses particulares como se fossem coletivos.

15 Esse é um recurso tão habitual que a sociedade brasileira já absorveu (foi convencida) que a realização da política de renúncia fiscal é uma política que beneficia a todos. Não por acaso, somente na Previdência (objeto de incontáveis contra-reformas que subtraem direitos dos trabalhadores) o governo Lula abriu mão de arrecadar tributos e contribuições previdenciárias que, apenas no ano de 2007, deve totalizar R\$ 65,5 bilhões (INCENTIVOS FISCAIS QUASE DOBRAM NO GOVERNO LULA, 2007). 
o grau de apatia, ignorância política e/ou desconfiança social para com a política institucional.

A partir de condições estruturalmente privilegiadas, empresários e seus aliados organizam sua intervenção por meio das esferas e das instâncias estatais, beneficiados pelo pressuposto liberal (dominante) de que o Estado constitui-se em instituição acima de interesses particulares de classes específicas e cuja finalidade é a realização do interesse público.

Nessas condições, o Parlamento, enquanto espaço de representação democrática e cuja particularidade histórica assegura certo ostracismo social, permite atuações identificadas com tais interesses sem, individualmente, revelar interesse de classe e/ou falta de compromisso com as promessas que permitiram a eleição.

Nessa relação triangular entre Estado, empresariado e sociedade, o poder Legislativo não é peça secundária ou coadjuvante; mesmo quando reconhecida a ascendência do poder Executivo em sistemas presidencialistas. Como constataram Argelina Figueiredo e Fernando Limongi, "o Executivo domina o processo legislativo porque tem poder de agenda e esta agenda é proces- sada e votada por um Poder Legislativo organizado de forma altamente centralizada em torno de regras que distribuem direitos parlamentares de acordo com princípios partidários" (FIGUEIREDO \& LIMONGI, 1999, p. 22).

Assim, se o poder Executivo detém o controle de agenda e de patronagem (Weber), os líderes partidários detêm poder de negociação e são instrumentos fundamentais para assegurar a unidade partidária ${ }^{16}$. De outra forma: a constituição de bancadas partidárias identificadas ideologicamente com os interesses empresariais no poder Legislativo, assim como a eleição de programa de governo inscrito sob a lógica de projeto de sociedade liberal ou suas variantes -, confere aos poderes Legislativo e Executivo uma unidade programática para além das siglas e das disputas pontuais.

\section{POR DENTRO DO PARLAMENTO CUIABA- NO E MATOGROSSENSE}

No extenso período pesquisado (1983-2004), foram dez as legislaturas estudadas (cinco estaduais e cinco municipais). Em cada uma delas, além dos eleitos, também foram considerados os suplentes que assumiram durante a Legislatura, perfazendo o seguinte quadro:

QUADRO 1 - NÚMERO DE ELEITOS E SUPLENTES NAASSEMBLÉIALEGISLATIVADE MATO GROSSO E NA CÂMARA MUNICIPAL DE CUIABÁ POR LEGISLATURA

\begin{tabular}{|l|l|l|l|l|l|}
\hline \multicolumn{4}{|l|}{ ASSEMBLÉIA LEG ISLA TIVA MATO GROSSO } & 17 & \multicolumn{3}{l|}{ CÂMARA MUNICIP AL DE CUIAB Á18 } \\
\hline LEGISLATURA & CONDIÇÄO & NÚMERO & LEGISLA TURA & CONDIÇÄO & NÚMERO \\
\hline 10 & ELEITOS & 24 & 11 & ELEITOS & 18 \\
$(1983 / 1986)$ & SUPLENTES & 08 & $(1983 / 1988)$ & SUPLENTES & 05 \\
11 & ELEITOS & 24 & 12 & ELEITOS & 21 \\
$(1987 / 1990)$ & SUPLENTES & 08 & $(1989 / 1992)$ & SUPLENTES & 07 \\
12 & ELEITOS & 24 & 13 & ELEITOS & 21 \\
$(1991 / 1994)$ & SUPLENTES & 15 & $(1993 / 1996)$ & SUPLENTES & 07 \\
\hline
\end{tabular}

16 De acordo com estudos realizados por Figueiredo e Limongi na Câmara dos Deputados (1989-1994), "em média, $89,4 \%$ do plenário vota de acordo com a orientação de seu líder, taxa suficiente para predizer com acerto de $93,7 \%$ das votações nominais" (FIGUEIREDO \& LIMONGI, 1999, p. 20).

17 Segundo o portal Excelências, o orçamento para a ALMT, em 2008, é de R\$ 151404 320,00, valor que, dividido pelos 24 deputados estaduais, atinge o montante de R\$ 6308 513,33 - um dos maiores do país. (Cf. EXCELÊNCIAS, 2008).

18 De acordo com o mesmo Portal, o orçamento de 2008 para a Câmara de Cuiabá é de R\$ 20420 000,00 (valor reajustado acima da inflação) e que, dividido pelos 19 vereadores, assegura a quantia de $\mathrm{R} \$ 1.074 .736,84$ por vereador (idem). 


\begin{tabular}{|c|c|c|c|c|c|}
\hline \multirow{2}{*}{$\begin{array}{l}13 \\
(1995 / 1998)\end{array}$} & ELEITOS & $23^{1}$ & \multirow{2}{*}{$\begin{array}{l}14 \\
(1997 / 2000)\end{array}$} & ELEITOS & 21 \\
\hline & SUPLENTES & 07 & & SUPLENTES & 11 \\
\hline \multirow{2}{*}{$\begin{array}{l}14 \\
(1999 / 2002)\end{array}$} & ELEITOS & 24 & \multirow{2}{*}{$\begin{array}{l}15 \\
(2001 / 2004)\end{array}$} & ELEITOS & 21 \\
\hline & SUPLENTES & 16 & & SUPLENTES & 08 \\
\hline \multirow{2}{*}{$\begin{array}{l}\text { TOTAL } \\
\text { (1983/2002) }\end{array}$} & ELEITOS & 119 & \multirow{2}{*}{\begin{tabular}{|l|} 
TOTAL \\
(1983/2004)
\end{tabular}} & ELEITOS & 102 \\
\hline & SUPLENTES & 54 & & SUPLENTES & 38 \\
\hline TOTAL GERAL & DEPUTADOS & 173 & TOTAL GERAL & VEREADORES & 140 \\
\hline
\end{tabular}

FONTE: Silveira (2007).

NOTA: 1. Na relação do TRE-MT, o nome do Deputado José Geraldo Riva consta como suplente. Na relação da Assembléia Legislativa do estado, o Deputado consta como eleito.

O Parlamento da capital é composto, majoritariamente, por matogrossenses. Diferentemente do senso comum que tende a considerar sub-representada a naturalidade regional, a Câmara Municipal de Cuiabá (CMC) registra uma média de
$42,15 \%$ de parlamentares nascidos na capital e $27,14 \%$ do interior do estado, conforme o Quadro 2. Essa média, entretanto, não é regular ao longo dos 22 anos estudados.

QUADRO 2-NATURALIDADE DOS PARLAMENTARES NAASSEMBLÉIALEGISLATIVADE MATO GROSSO E NACÂMARA MUNICIPAL DE CUIABÁ (\%)

\begin{tabular}{|c|c|c|c|c|c|c|c|c|c|c|}
\hline \multirow[b]{2}{*}{ NATURALIDADE } & \multicolumn{5}{|c|}{ ASSEMBLÉIA LEGISLATIVA } & \multicolumn{5}{|c|}{ CÂMARA MUNICIPAL CUIABÁ } \\
\hline & $10^{3}$ & $11^{3}$ & $12^{3}$ & $13^{\circ}$ & $14^{3}$ & $11^{3}$ & $12^{3}$ & $13^{\circ}$ & $14^{3}$ & $15^{\circ}$ \\
\hline CUIABÁ & 15,63 & 12,50 & 7,69 & 13,33 & 10 & 39,13 & 60,72 & 53,58 & 34,36 & 24,14 \\
\hline INTERIOR MT & 37,50 & 37,50 & 23,08 & 30 & 20 & 43,47 & 14,29 & 14,29 & 37,50 & 27,58 \\
\hline SÃ̃O PAULO & 25 & 21,89 & 20,52 & 16,67 & 7,50 & 4,35 & 10,71 & 3,57 & 3,13 & 13,79 \\
\hline MINAS GERAIS & 12,50 & 12,50 & 7,69 & 6,67 & 17,50 & 0,00 & 0,00 & 10,71 & 9,37 & 3,45 \\
\hline $\begin{array}{l}\text { MATO GROSSO } \\
\text { SUL }\end{array}$ & 0,00 & 3,12 & 2,56 & 0,00 & 15 & 4,35 & 3,57 & 7,14 & 3,13 & 6,90 \\
\hline GOIÁS & 0,00 & 6,25 & 5,13 & 0,00 & 5 & 0,00 & 3,57 & 10,71 & 6,25 & 0,00 \\
\hline $\begin{array}{l}\text { OUTROS } \\
\text { ESTADOS }\end{array}$ & 9,37 & 6,24 & 33,33 & 33,33 & 25 & 8,70 & 7,14 & 0,00 & 6,26 & 6,90 \\
\hline $\begin{array}{l}\text { SEM } \\
\text { INF ORMAÇÄO }\end{array}$ & 0,00 & 0,00 & 0,00 & 0,00 & 0,00 & 0,00 & 0,00 & 0,00 & 0,00 & 17,24 \\
\hline TOTAL & 100 & 100 & 100 & 100 & 100 & 100 & 100 & 100 & 100 & 100 \\
\hline
\end{tabular}

FONTE: Silveira (2007).

Embora a Câmara Municipal revele um claro predomínio de matogrossenses, somente nas $12^{\mathrm{a}} \mathrm{e}$ $13^{\text {a }}$ legislaturas observa-se uma superioridade numérica daqueles nascidos na capital do estado. Se esse dado, entretanto, não altera o perfil da Câmara no que diz respeito à representação regional, na Assembléia Legislativa de Mato Grosso (ALMT), constata-se uma média de $11,56 \%$ de parlamentares nascidos na Capital e $28,90 \%$ no interior do estado, o que significa uma sub-representação re- gional na Casa Legislativa estadual, especialmente se considerarmos as três últimas legislaturas.

Conseqüentemente, a representação regional é - na média - suplantada por parlamentares originários de outros estados: $41 \%$ versus $59 \%$, destacando-se, nesse universo, paulistas e mineiros. Tal composição parece refletir o perfil do estado de Mato Grosso, objeto das políticas de colonização dos anos 1970 que atraíram levas de migrantes, especialmente das regiões do sul do país. 
Ao acolher amplos contingentes de migrantes, o estado matogrossense transformou-se no território de muitos ditos "desbravadores", seduzidos pelas propagandas oficiais. Contudo, apesar de ser considerada a região que mais "exportou" migrantes para Mato Grosso, o Sul do país não tem representação equivalente em nenhuma das Casas Legislativas. Apenas na $12^{\mathrm{a}}$ os gaúchos e catarinenses alcançaram, cada um, 10,26\% da representação estadual. Os paranaenses, por sua vez, na $14^{\mathrm{a}}$ Legislatura, alcançaram $15 \%$ da composição da ALMT.
Entretanto, se os matogrossenses estão relativamente bem representados no poder Legislativo, as mulheres são imensamente sub-representadas. Assim, se considerarmos que, em 2000 (segundo dados do IBGE), o MT possuía população total de 2504353 habitantes, sendo 1.287.187 homens e 1217166 mulheres, a representação feminina na ALMT (Quadro 3) não atingiu sequer 10\% na Legislatura com maior presença $\left(13^{\mathrm{a}}\right)$. Na $10^{\mathrm{a}}$ Legislatura nenhuma mulher assumiu, sequer na condição de suplente.

QUADRO 3 - PROPORÇÃO DE HOMENS EM MULHERES POR LEGISLATURA (\%)

\begin{tabular}{|c|c|c|c|c|c|c|c|c|c|c|}
\hline \multirow[b]{2}{*}{ SEXO } & \multicolumn{5}{|c|}{ ASSEMBLÉIA LEGISLATIVA } & \multicolumn{5}{|c|}{ CÂMARA MUNICIPAL CUIABÁ } \\
\hline & $10^{3}$ & $11^{3}$ & $12^{2}$ & $13^{\circ}$ & $14^{3}$ & $11^{3}$ & $12^{3}$ & $13^{\circ}$ & $14^{3}$ & $15^{3}$ \\
\hline HOMENS & 100 & 97 & 95 & 93 & 98 & 100 & 100 & 96 & 94 & 86 \\
\hline MULHERES & 0,00 & 3 & 5 & 7 & 2 & 0,00 & 0,00 & 4 & 6 & 14 \\
\hline TOTAL & 100 & 100 & 100 & 100 & 100 & 100 & 100 & 100 & 100 & 100 \\
\hline
\end{tabular}

FONTE: Silveira (2007).

A situação não foi diferente na Câmara Municipal de Cuiabá. Observa-se, entretanto, uma tímida tendência de aumento na representação feminina a partir da $13^{\text {a }}$ Legislatura, com um percentual que avança de menos de $4 \%$ para quase $14 \%$. Nesse sentido, importa registrar que Cuiabá concentrava, em 2000, população total de 483346 habitantes, divididos em 235568 homens e 247778 mulheres.
Avançando na análise do perfil sócio-econômico $^{19}$ dos 221 parlamentares eleitos e dos 92 suplentes que assumiram no período, considerando tanto a ALMT quanto a CMC (Quadro 4), é possível identificar uma forte predominância de parlamentares com ensino superior completo: $68,32 \%$ na $\mathrm{CMC}$ e $54,65 \%$ na ALMT.

QUADRO 4 - GRAU DE ESCOLARIDADE DOS PARLAMENTARES DA ASSEMBLÉIA LEGISLATIVA E DA CÂMARA MUNICIPAL DE CUIABÁ (\%)

\begin{tabular}{|c|c|c|c|c|c|c|c|c|c|c|}
\hline \multirow[b]{2}{*}{ ESCOLARID ADE } & \multicolumn{5}{|c|}{ ASSEMBLÉIA LEGISLATIVA } & \multicolumn{5}{|c|}{ CÂMARA MUNICIPAL CUIABÁ } \\
\hline & $10^{\circ}$ & $11^{3}$ & $12^{3}$ & $13^{\circ}$ & $14^{3}$ & $11^{3}$ & $12^{3}$ & $13^{\circ}$ & $14^{3}$ & $15^{3}$ \\
\hline $1^{\circ} \mathrm{Grau}$ Completo & 3,12 & 3,12 & 0,00 & 3,33 & 0,00 & 0,00 & 0,00 & 0,00 & 0,00 & 0,00 \\
\hline $\begin{array}{l}1^{\circ} \mathrm{Grau} \\
\text { Incompleto }\end{array}$ & 0,00 & 0,00 & 7,69 & 0,00 & 2,5 & 0,00 & 0,00 & 0,00 & 0,00 & 0,00 \\
\hline $2^{\circ}$ Grau completo & 28,12 & 12,50 & 30,78 & 33,34 & 40 & 21,74 & 10,71 & 25 & 25 & 13,79 \\
\hline $\begin{array}{l}2^{\circ} \mathrm{Grau} \\
\text { Incompleto }\end{array}$ & 6,26 & 3,12 & 2,56 & 0,00 & 0,00 & 4,35 & 0,00 & 0,00 & 0,00 & 0,00 \\
\hline $3^{\circ}$ Grau Completo & 56,26 & 65,63 & 53,85 & 60 & 37,50 & 73,91 & 85,72 & 64,29 & 62,50 & 55,18 \\
\hline $\begin{array}{l}3^{\circ} \mathrm{Grau} \\
\text { Incompleto }\end{array}$ & 3,12 & 9,38 & 2,56 & 3,33 & 12,50 & 0,00 & 3,57 & 10,71 & 12,50 & 13,79 \\
\hline Sem Informaçẫo & 3,12 & 6,25 & 2,56 & 0,00 & 7,5 & 0,00 & 0,00 & 0,00 & 0,00 & 17,24 \\
\hline TOTAL & 100 & 100 & 100 & 100 & 100 & 100 & 100 & 100 & 100 & 100 \\
\hline
\end{tabular}

FONTE: Silveira (2007).

19 Essa pesquisa esforçou-se por obter os seguintes dados: a) naturalidade; b) escolaridade; c) profissão e d) trajetória política partidária. Registramos as enormes dificuldades para esse levantamento, principalmente pela falta de dados disponíveis na Câmara Municipal de Cuiabá e, em $\overline{\text { menor proporção, na Assembléia Legislativa do Estado de }}$ Mato Grosso. Parte significativa desses dados foi obtida por meio de um intenso, exaustivo e longo trabalho de garimpagem que envolveu, inclusive, localização de ex-parlamentares e/ou familiares, tanto no interior de MT quanto em outros estados. 
Comparativamente, a Câmara Municipal apresenta um quadro com percentuais mais significativos de parlamentares com curso superior. Porém, as duas últimas legislaturas pesquisadas $\left(14^{\mathrm{a}}\right.$ na ALMT e $15^{\mathrm{a}}$ na CMC), convergem para um refluxo nos percentuais de legisladores com formação superior. Na ALMT, a $14^{\mathrm{a}}$ Legislatura registra, inclusive, a superioridade numérica daqueles que têm somente o $2^{\circ}$ Grau Completo.

Consideradas, entretanto, quais as principais áreas de formação universitária, o curso de Direi- to (exclusiva ou conjugada a outros cursos de nível superior) garante ascendência acadêmica em todas as legislaturas da ALMT e em três legislaturas da $\mathrm{CMC}$, perdendo apenas para a Administração de Empresas nas últimas duas legislaturas municipais.

Tais percentuais são expressivos, principalmente se observarmos que os demais cursos superiores informados são pulverizados, atingindo em média $1 / 3$ das indicações para Direito.

\section{QUADRO 5 - ÁREA DE FORMAÇÃO DOS LEGISLADORES (\%)}

\begin{tabular}{|c|c|c|c|c|c|c|c|c|c|c|}
\hline \multirow[t]{2}{*}{$\begin{array}{l}\text { FORIMAÇÄO } \\
\text { AC ADÊMIC A }^{\prime}\end{array}$} & \multicolumn{5}{|c|}{$\begin{array}{l}\text { ASSEMBLÉIA } \\
\text { LEGISLA TIVA }\end{array}$} & \multicolumn{5}{|c|}{$\begin{array}{l}\text { CÂMARA MUNICIPAL } \\
\text { CUIABÁ } \\
\end{array}$} \\
\hline & $10^{3}$ & $11^{3}$ & $12^{3}$ & $13^{\circ}$ & $14^{3}$ & $11^{3}$ & $12^{3}$ & $13^{3}$ & $14^{3}$ & $15^{3}$ \\
\hline $\begin{array}{l}\text { ADMINNSTR. } \\
\text { EMPRESAS }\end{array}$ & 0,00 & 4,76 & 4,76 & 0,00 & 6,67 & 5,88 & 4,17 & 5,55 & 20,00 & 18,75 \\
\hline AGRONOMIA & 0,00 & 9,53 & 4,76 & 5,55 & 0,00 & 5,88 & 4,17 & 0,00 & 5 & 12,50 \\
\hline ARQUITETURA & 0,00 & 0,00 & 0,00 & 0,00 & 0,00 & 0,00 & 0,00 & 11,11 & 5 & 6,25 \\
\hline $\begin{array}{l}\text { CIENNCIAS } \\
\text { CONTABEEIS }\end{array}$ & 0,00 & 0,00 & 0,00 & 5,55 & 6,67 & 11,77 & 0,00 & 0,00 & 0,00 & 0,00 \\
\hline DIREITO & 49,99 & 52,38 & 47,61 & 61,10 & 46,66 & 47,06 & 45,83 & 27,78 & 10 & 6,25 \\
\hline ECONOMIA & 5,55 & 0,00 & 9,53 & 0,00 & 0,00 & 5,88 & 8,33 & 11,11 & 5 & 0,00 \\
\hline $\begin{array}{l}\text { ENGENHARIA } \\
\text { CVIL }\end{array}$ & 16,67 & 14,29 & 14,29 & 16,70 & 13,33 & 0,00 & 0,00 & 16,67 & 10 & 6,25 \\
\hline MEDICINA & 5,56 & 4,76 & 14,29 & 5,55 & 13,33 & 11,77 & 29,16 & 22,23 & 10 & 12,50 \\
\hline $\begin{array}{l}\text { OURROS } \\
\text { CURSOS }\end{array}$ & 22,23 & 14,28 & 4,76 & 5,55 & 13,34 & 11,76 & 8,34 & 5,55 & 25 & 37,50 \\
\hline $\begin{array}{l}\text { SEM } \\
\text { INFORMAÇÃOO }\end{array}$ & 0,00 & 0,00 & 0,00 & 0,00 & 0,00 & 0,00 & 0,00 & 0,00 & 10 & 0,00 \\
\hline TOTAL & 100 & 100 & 100 & 100 & 100 & 100 & 100 & 100 & 100 & 100 \\
\hline
\end{tabular}

FONTE: Silveira (2007).

NOTA: 1. Considera-se aqui a formação exclusiva ou paralela a outras áreas de formação superior, a partir da prevalência daqueles cursos com maior recorrência.

Analisando o quadro de formação acadêmica, algumas observações podem ser feitas: a primeira é que o espaço legislativo revela-se como uma alternativa para operadores do Direito; a segunda é que enquanto os engenheiros aparecem como a segunda formação acadêmica mais comum na ALMT, os médicos parecem mais afeitos ao poder Legislativo local.

A escolaridade, embora não seja sinônimo de compromisso social, é um importante instrumento de averiguação quanto ao acesso aos mais elementares direitos da cidadania. Porém, na medida em que a escola não é um espaço de conhecimento neutro, nem tampouco descolado das exigên- cias do mercado e da lógica civilizatória do capitalismo, altos índices de escolaridade em níveis superiores não nos indica atuação parlamentar socialmente referenciada ${ }^{20}$.

Dessa forma, na medida em que a representação por dentro do Estado é fundamental para articular a aprovação de interesses de classe e de gru-

20 A análise da atuação parlamentar, principalmente por meio das leis aprovadas e sua respectiva autoria, é objeto de outra pesquisa que está em fase de conclusão (cf. SILVEIRA, 2007). Porém, já é possível adiantar que a relação formação superior/compromisso social não encontra guarita nos fatos. 
pos específicos, é relevante observar a composição da ALMT e da CMC (Quadro 6), conferindo o percentual de empresários ${ }^{21}$, de profissionais liberais e de assalariados representados em ambos os parlamentos.
E, embora tendo claro que a condição salarial não é condição automática para identificar compromisso de classe, é expressivo que por mais de 20 anos os trabalhadores sejam sub-representados (considerando-se, nesse particular, a proporção social no estado e no município).

QUADRO 6 - PROFISSÃO DOS PARLAMENTARES (\%)

\begin{tabular}{|c|c|c|c|c|c|c|c|c|c|c|}
\hline \multirow[t]{2}{*}{ PROFISSÃO } & \multicolumn{5}{|c|}{ ASSEMBLÉIA LEGISLATIVA } & \multicolumn{5}{|c|}{ CÂMARA MUNICIPAL CUIABÁ } \\
\hline & $10^{\circ}$ & $11^{3}$ & $12^{3}$ & $13^{\circ}$ & $14^{\circ}$ & $11^{3}$ & $12^{3}$ & $13^{\circ}$ & $14^{0}$ & $15^{\circ}$ \\
\hline ASSALARIADOS & 18,75 & 21,87 & 20,51 & 20 & 20 & 21,73 & 21,43 & 21,43 & 25 & 6,90 \\
\hline EMPRESÁRIOS & 50 & 31,25 & 46,15 & 36,67 & 45 & 8,70 & 3,57 & 14,28 & 18,75 & 13,80 \\
\hline $\begin{array}{l}\text { PROFISSIONAIS } \\
\text { UEERAIS }\end{array}$ & 31,25 & 46,88 & 33,34 & 43,33 & 30 & 65,22 & 75 & 60,72 & 53,12 & 51,72 \\
\hline OUTRA $^{1}$ & 0,00 & 0,00 & 0,00 & 0,00 & 5 & 4,35 & 0,00 & 3,57 & 3,13 & 10,34 \\
\hline $\begin{array}{l}\text { SEM } \\
\text { INF ORMAÇ̃̃OO }\end{array}$ & 0,00 & 0,00 & 0,00 & 0,00 & 0,00 & 0,00 & 0,00 & 0,00 & 0,00 & 17,24 \\
\hline TOTAL & 100 & 100 & 100 & 100 & 100 & 100 & 100 & 100 & 100 & 100 \\
\hline
\end{tabular}

FONTE: Silveira (2007).

NOTA: 1. Pastor da Igreja Universal; político; estudante; técnico em telecomunicações.

Na ALMT (1983-2002), enquanto os empresários foram $41,81 \%$ dos parlamentares e os profissionais liberais $36,96 \%$, os assalaria$\operatorname{dos}^{22}$ atingiram 20,23\%. Nessas condições, há uma regularidade percentual entre as três grandes classificações profissionais, com alternância de ascendência entre empresários e profissionais liberais, embora os primeiros assegurem superioridade média.

Na CMC (1983-2004), ao contrário, há forte prevalência dos profissionais liberais. Eles chegam a participar com uma média de $61,16 \%$ ao longo dos 22 anos pesquisados. $\mathrm{O}$ empresariado, em contraposição, não alcança $12 \%$, sendo superado mesmo pelos assalariados, que chegaram a compor $19,30 \%$ no seu melhor momento. Tais

21 Os empresários atuam, especialmente, na Pecuária e na Agropecuária. Muitos deles, inclusive, indicam sua atividade profissional, agregando também sua formação acadêmica. Ex.: Agropecuarista e Engenheiro Civil.

22 Classificados como tais professores, servidores públicos, bancários e comerciários. percentuais parecem indicar o Parlamento Municipal como um locus privilegiado de profissionais liberais, o que corrobora o perfil universitário apresentando anteriormente.

$\mathrm{Na}$ ALMT, os parlamentares subordinam a sua formação acadêmica à atividade econômica, o que os leva a indicar a atividade empresarial, efetivamente, como credencial profissional. Daí porque, apesar da prevalência de operadores do Direito em ambas as casas, essa superioridade não se revela na tabela das profissões da ALMT.

Considerando-se, entretanto, quais as principais áreas de atuação dos profissionais liberais, os advogados, como era de se esperar, atingem uma média de $42,87 \%$ na ALMT. Na $13^{\text {a }}$ Legislatura chegaram a representar $53,85 \%$ dos parlamentares estaduais. Em segundo lugar estão os médicos, que têm uma média de $11,11 \%$ ao longo do período pesquisado.

Na Câmara Municipal, também advogados gozam de primazia entre os profissionais liberais: $27,06 \%$. A melhor participação dos advogados foi na $11^{\text {a }}$ Legislatura, quando somaram $46,66 \%$ dos 
parlamentares municipais. Depois, essa representação passou a decrescer significativamente, chegando aos 6,67\% na última Legislatura municipal estudada. Essa perda de $40 \%$ na representação dos operadores jurídicos não foi preenchida por nenhuma outra área profissional específica, mas, como já foi antecipado, distribuída em um conjunto de áreas de conhecimento.

A Medicina foi a segunda profissão liberal mais participativa na composição da Câmara Municipal: 18,82\% em média. Sua maior participação ocorreu na $13^{\mathrm{a}}$ Legislatura, quando atingiu $23,53 \%$ e sua menor representatividade ocorreu na $11^{\mathrm{a}} \mathrm{e}$ $13^{\mathrm{a}}$, quando atingiu 13,33\%. As profissões de Engenheiro Civil, Administrador de Empresas e Economista também despontaram com médias de $8,23 \%$ e $7,06 \%$, respectivamente, sendo que a profissão de Administrador e Economista registrou o mesmo percentual.

\section{O PERFIL POLÍTICO EA TRAJETÓRIA PAR- TIDÁRIADO PARLAMENTO MUNICIPALE ESTADUAL}

A opção pelo recorte "político e partidário" não é gratuita. Ela atende à necessidade de abranger tanto a atuação política fora da institucionalidade estatal quanto aquela que diz respeito à trajetória partidária dos parlamentares, embora, inegavelmente, sejam parte de uma mesma unidade.

Em verdade, a correspondência entre atuação parlamentar e trajetória partidária, articulada com uma atuação fora dos espaços institucionais, é inescapável. E revelam aspectos importantes dos caminhos legiferantes do próprio Parlamento.

Nesse sentido, identificar eventuais participações ${ }^{23} \mathrm{em}$ organizações coletivas tornouse um imperativo para que eu pudesse traçar um perfil mais fidedigno do Parlamento Municipal (Gráfico 1) e Estadual (Gráfico 2), durante o período de 22 e 20 anos, respectivamente.

\footnotetext{
23 Na medida em que os dados que me permitiu traçar este “perfil participativo" foi resultado, fundamentalmente, da compilação de currículos, material de propaganda eleitoral e, eventualmente, entrevista com algum parlamentar (diante da inexistência de qualquer registro nas Casas pesquisadas), tais dados, necessariamente, devem ser relativizados, considerando-se as enormes dificuldades no levantamento, o que implica dizer que refletem e devem ser compreendidos na dimensão das informações obtidas.
}

Considerando que muitos parlamentares são reconduzidos ao cargo (como veremos mais adiante), ao todo foram 94 parlamentares pesquisados na Câmara Municipal e 119 na Assembléia Legislativa do estado de Mato Grosso, embora haja trânsito, também, entre ambas as casas. Entretanto, nesse levantamento fiz um corte por Parlamento, analisando parlamentares que, como suplente ou eleito, assumiram a Casa em questão, ao menos uma vez durante todo o período estudado.

Dessa forma, observei que apenas $38,30 \%$ dos parlamentares municipais participaram de alguma organização fora da institucionalidade estatal, abrangendo o antes e o depois da eleição. Como dos poucos parlamentares que em algum momento participaram de alguma organização coletiva (exceção ao partido político), muitos atuaram (ou atuam) em mais de uma organização social, optei considerar os tipos de organização que, isoladamente, despertaram (ou despertam) a preferência parlamentar.

Primeiramente, importa registrar que dentre aqueles que registram alguma forma de participação, o maior percentual de atuação está concentrado no período anterior à eleição: $66,67 \%$. Outros $22,22 \%$ passaram a atuar após a eleição e $11,11 \%$ mantêm atuação após a eleição.

Dentre as organizações coletivas que gozam de preferência parlamentar, as associações sociais e/ou populares ${ }^{24}$ são aquelas que alcançam maior concentração de interesse, conforme podemos observar no Gráfico 1.

24 A título de esclarecimento, foram qualificadas como associação institucional as organizações relacionadas ao exercício do poder institucional, tais como a União de Vereadores ou o Conselho dos Delegados da Educação; como associação profissional, a $\mathrm{OAB}$, a Associação dos Médicos etc.; como associação social e/ou popular, as associações comunitárias, associações de moradores, Direito dos Povos, MST, Proteção ao Meio Ambiente etc.; como entidade assistencial e/ou comunitária, o Clube de Mães, Escoteiros, associação de deficientes, Rotary Club, Fundação Médico-Assistencial dos Trabalhadores Rurais etc.; como entidades empresariais, o Sebrae, o SESC, o Senai etc.; como entidades patronais, sindicatos, associações, federações de empresários, independentemente do ramo de atividade e entidades recreativas como associações esportivas, clubes de futebol etc. 
GRÁFICO 1-ATUAÇÃO EM ORGANIZAÇÕES COLETIVAS PELOS VEREADORES DE CUIABÁ $-11^{\mathrm{a}}$ À $14^{\mathrm{a}}$ LEGISLATURAS (1983-2004)

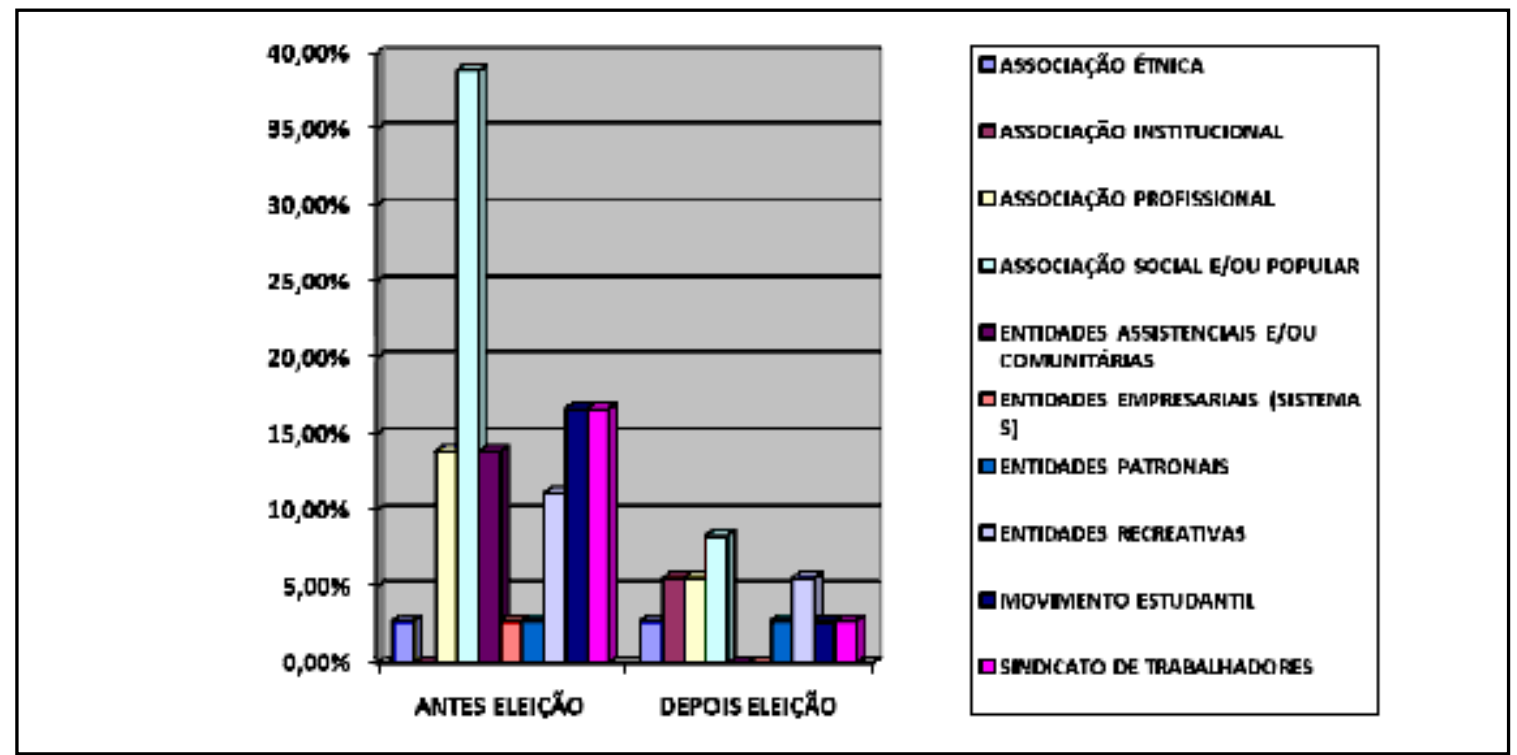

FONTE: Silveira (2007)

NOTA: Universo de 94 vereadores.

Dos 36 parlamentares que têm (ou tiveram) alguma atuação extra-partidária, a maioria atua (ou atuou) em mais de uma entidade: $58,35 \%$ dentre os ativos antes da eleição; 19,44\% dentre os ativos depois das eleições e 11,11\% daqueles que se mantêm atuantes mesmo após a eleição.

O que podemos extrair desse quadro? Primeiramente, que não há tradição quanto à participação em organizações coletivas por parte dos parlamentares, mesmo antes das eleições; o que nos leva a refletir sobre os meios/recursos que são utilizados pelos parlamentares para conquistar o voto do eleitor ${ }^{25}$. Em segundo lugar, associações sociais e/ou populares, assim como sindicatos de trabalhadores e movimento estudantil desfrutam de prestígio antes das eleições. Ao garantir visibilidade pública, constituem-se em espaço atraente para a alavancagem política institucional para muitos dos futuros parlamentares.

A questão, portanto, não está na promoção eleitoral que tais espaços públicos propiciam, mas na relação que o agente político estabelece com tais

25 As motivações do voto tanto em Cuiabá quanto em Várzea Grande foram objeto de pesquisa da autora nas eleições de 2000, cujos resultados estão publicados no livro Memória Social \& Processo Eleitoral (SILVEIRA, 2002). organizações após o processo eleitoral. Na maioria dos casos, o parlamentar ou o governante descola-se das demandas que ajudou a tornar públicas - e das quais se beneficiou eleitoralmente -, e passa a assumir o discurso abstrato do interesse de "toda a sociedade", a partir do qual se apresenta como representante do interesse coletivo supra-classe.

Na medida, porém, em que o interesse comum é uma abstração irrealizável em sociedades socialmente desiguais - como bem ensinou Rousseau -, a abstração discursiva acaba por servir àqueles que, ideologicamente, têm seus interesses associados ao interesse de toda a sociedade. Trata-se da lógica econômica liberal, segundo a qual o agente econômico privado, ao perseguir seu interesse particular, acaba por realizar o interesse coletivo, isto é: ao perseguir o lucro, dinamiza as relações econômicas, desencadeando um processo de desenvolvimento muito além da realização privada dos seus interesses, como emprego (direto e indireto), consumo, receitas públicas etc.

Por outro lado, há que se registrar a preferência parlamentar por associações sociais e/ou populares: $47,22 \%$, se considerarmos antes e depois das eleições. Quando analisadas mais de perto - a partir das indicações relacionadas nos currículos parlamentares - observa-se que tais associações são predominantemente relacionadas às 
atividades de bairro (Associação de Moradores, por exemplo), as quais não contabilizam atuações autônomas em relação ao poder instituído. Em muitos casos, caracterizam-se por relações de apadrinhamento e clientelismo político, constituindo-se em verdadeiros redutos eleitorais.

Nesse aspecto, embora a atuação coletiva seja, na maioria das vezes, um importante instrumento de educação política ${ }^{26}$, é preciso relativizar tais números, posto que a indicação de participação em organizações sociais não assegura, necessariamente, qualidade política. Determinadas direções podem contribuir para a "deformação política" em vez de educar para o compromisso coletivo.

Por fim, considerados os 22 anos estudados 27 e os 94 vereadores que passaram pela Câmara Municipal de Cuiabá, apenas 36 indicaram alguma participação em organizações coletivas. Relacionando tais parlamentares com os partidos pelos quais passaram, não é possível, entretanto, estabelecer uma relação de correspondência, principalmente porque a conformação partidária de oposição em Mato Grosso (especialmente durante o regime militar) revela frágil consistência, conforme veremos mais adiante. Apesar disso, é possível observar que o PMDB foi o partido que durante algum momento fez parte da alternativa partidária de $50 \%$ desses parlamentares.

Em decorrência da "fluidez" partidária que particulariza o universo mato-grossense, $38,89 \%$ dos parlamentares que têm ou tiveram alguma participação coletiva extra-partidária foram (ou são) filiados a partidos com certa proximidade a organizações coletivas, e outros $47,22 \%$ filiaram-se tanto a partidos que nacionalmente têm tradição em organizações coletivas quanto a partidos que não têm um histórico em organização popular: Arena, PDS, PFL, PPB, PL, PMN, PSL e PSC ${ }^{28}$.

Tal quadro, entretanto, não é prerrogativa dos vereadores. Dentre os deputados estaduais a situação não é melhor. Ao contrário. Durante os 20 anos ${ }^{29} \mathrm{e}$ dos 119 parlamentares pesquisados, apenas 26 - ou seja, $21,85 \%$ - indicaram alguma organização coletiva.

GRÁFICO 2 - ATUAÇÃO EM ORGANIZAÇÕES COLETIVAS PELOS DEPUTADOS ESTADUAIS - $10^{\mathrm{a}} \mathrm{A} 14^{\mathrm{a}}$ LEGISLATURAS (1983-2002)

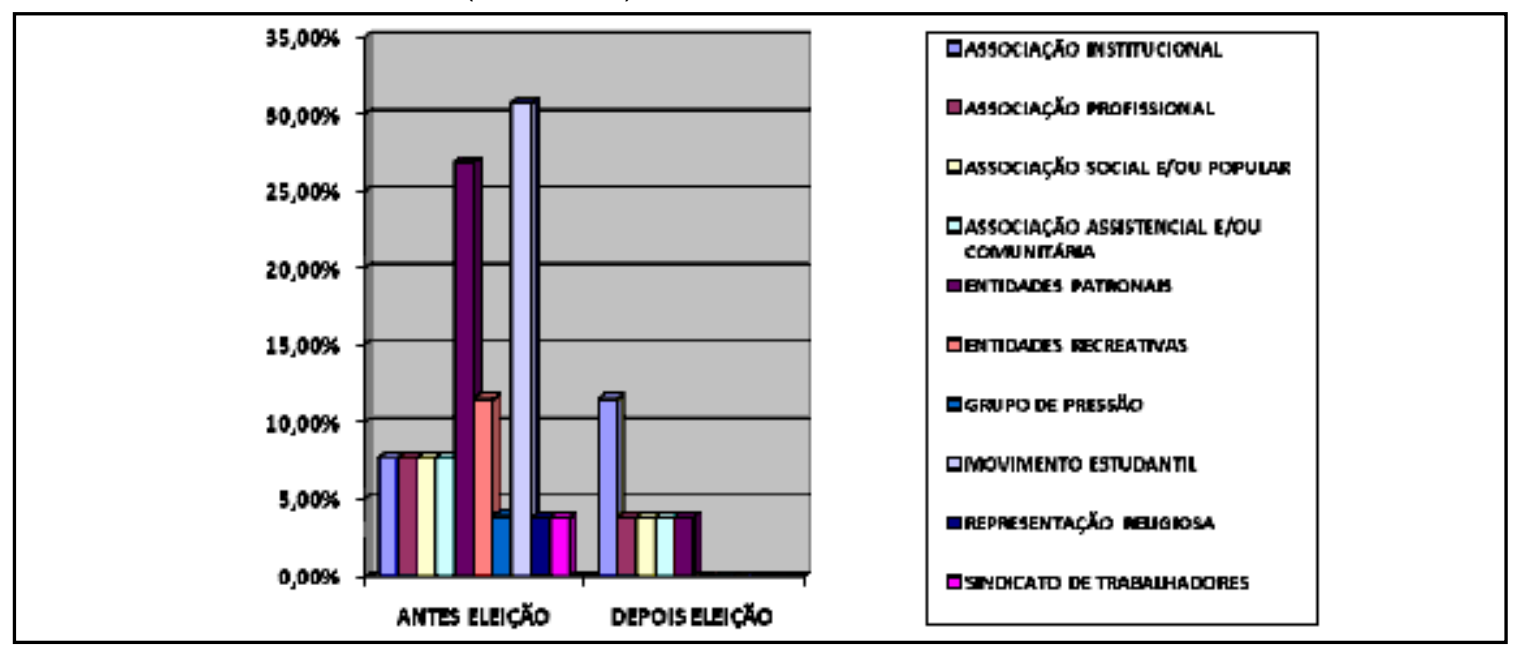

FONTE: Silveira (2007)

NOTA: Universo de 119 deputados estaduais.

26 Trata-se, aqui, de recuperar o conceito de educação política no sentido de educar para a democracia social e a capacidade de respeito e compromisso ao interesse coletivo. Ao contrário disso, muitos valem-se das associações coletivas como forma de cristalizar relações de clientela e de messianismo populista.

27 Durante esse período, passaram pela Prefeitura Municipal de Cuiabá: Gustavo Arruda, do PDS (1979-1983); Anildo Lima Barros, do PDS (1983-1985); Wilson Araújo
Coutinho, do PMDB (1985); Dante Martins de Oliveira, do PMDB (1986); Estevão Torquato da Silva, do PMDB (1986-1987); Alfredo Ferreira da Silva-Procurador Municipal (1987); Frederico Carlos Soares Campos, do PFL (1989-1992); Dante Martins de Oliveira, do PDT (19931994); José Meirelles, do PSDB (1994-1996); Carlos Brito de Lima, do PSDB (1996); Roberto França Auad, do PSDB/ PPS (1997-2000 e 2001-2004).

28 O PTB não foi considerado nessa classificação por não se ajustar - em outros tempos, especialmente antes da 
Novamente, a situação reproduz-se, porém agravada: $70,08 \%$ desses parlamentares atuaram antes da eleição, 19,23\% passaram a atuar depois de eleitos e 7,69\% mantêm-se atuantes. Desses raros parlamentares com alguma proximidade com organizações coletivas, $42,31 \%$ atuaram em mais de uma entidade e 7,69\% mantêm atuação em duas entidades ou mais. Daqueles que passaram a atuar após a eleição, $15,38 \%$ atuam em apenas uma organização coletiva.

No caso dos deputados estaduais, o berço da atuação política é o movimento estudantil $(30,76 \%)$, seguido de perto pelas entidades patronais $(26,92 \%)$. Entretanto, após a eleição, são as associações institucionais que ascendem como formas de organização coletiva extra-partidária (11,53\%). Assim, corroborando o perfil sócioeconômico dos deputados, as entidades patronais constituem importante segmento de representação política.

Analisados os partidos políticos pelos quais esses parlamentares em algum momento foram filiados, observa-se, também, a ascendência do PMDB: $46,15 \%$. Considerando a filiação tanto a partidos do campo de resistência democrática quanto àqueles que deram sustentação à ditadura - conforme recorte a ser desenvolvido adiante $34,61 \%$ dos parlamentares atuantes vêm dessa mescla partidária; mesmo percentual daqueles deputados cuja trajetória partidária restringe-se àqueles partidos sem tradição em organização popular: UDN, ARENA, PDS, PFL, PRN, PSC, DEM, PPB, PP, PR, PL e PMN. No caso do chamado campo de resistência democrática, o percentual é de $30,78 \%$.

Assim, as considerações feitas sobre os vereadores são ainda mais adequadas aos deputados: os parlamentares não têm vínculos orgânicos com organizações coletivas para além dos partidos políticos. A esmagadora maioria parece incorporar 0

ditadura militar (1964-1985) - a esse critério de seleção.

29 À frente do poder Executivo estadual estiveram os seguintes governadores: Frederico Carlos Soares Campos, da Arena (1979-1983); Júlio José de Campos, do PDS (1983-1986); Wilmar Peres, do PDS (1986-1987); Carlos Gomes Bezerra, do PMDB (1987-1990); Edison de Freitas, do PMDB (1990-1991); Moisés Feltrin, do PFL (1991); Jayme Veríssimo de Campos, do PFL (1991-1994); Dante Martins de Oliveira, do PDT/PSDB (1995-1998 e 19992002) e José Rogério Sales, do PSDB (2002). pressuposto de representantes coletivos sem vínculos imperativos ${ }^{30}$, embora seja perfeitamente demonstrável que tal pressuposto não encontra efetividade na atuação estatal. Trata-se, portanto, muito mais de um discurso de representação livre do que de realidade fática.

Nessa perspectiva, o distanciamento de organizações coletivas de natureza popular, social, sindical, comunitária ou estudantil, por exemplo, parece indicar muito mais certa autopercepção de auto-suficiência parlamentar que lhes isenta de referência social mais orgânica. Assim, a partir dessa autopercepção, a tais organizações, lhes é reservada uma relação eqüidistante de representação geral. Tal percepção e conseqüente atuação, que a princípio parece indicar isenção legiferante, não encontram respaldo nas práticas cotidianas do Parlamento, conforme a análise da atuação parlamentar no mesmo período que fizemos em outra pesquisa em processo de conclusão (cf. SILVEIRA, 2007).

Então, se as organizações coletivas não são fonte de interlocução social para os parlamentares, os partidos políticos apresentam-se como as únicas instituições que mantêm certa "ascendência" sobre deputados e vereadores.

Nesse particular cabem algumas considerações preliminares. Os partidos políticos são veículos privilegiados para a organização coletiva e a disputa eleitoral de um determinado projeto de sociedade $^{31}$. Dessa forma, a centralidade das campanhas eleitorais, fundada sobre a figura dos candi-

30 De acordo com Norberto Bobbio, "jamais uma norma constitucional foi mais violada que a proibição de mandato imperativo", na medida em que se trata de uma regra sem sanção (BOBBIO, 1992, p. 24-25). De outra forma: a idéia de mandato livre implica aceitar o pressuposto de que a representação não responde àqueles que elegeram o representante, mas ao conjunto dos eleitores. Nesse sentido, os eleitos parecem - e apenas parecem e quando lhes convêm - descolar-se dos interesses particulares dos grupos e segmentos que o elegeram para representar o conjunto da sociedade.

31 Dados os limites desse artigo, não cabe aqui a apresentação dos principais projetos políticos e sociais que orientam o projeto de sociedade em âmbito, inclusive, internacional: o liberalismo clássico, o socialismo, a social-democracia, o neoliberalismo e a governança progressista. A análise desses projetos foi feita pela autora em outro trabalho, intitulado Caderno de Teoria Política (SILVEIRA, 2000), onde consta, também, a indicação bibliográfica específica. 
datos e em suas características pessoais, não reflete a centralidade da política com que efetivamente conta no processo decisório. Porém, esse procedimento é conveniente para prender a atenção do cidadão, induzindo-o a acreditar que a disputa eleitoral é entre personagens e não entre projetos. Quanto mais convicto estiver o eleitor desse processo, mais facilmente o projeto é preservado quando eventuais desgastes políticos atingem certos homens públicos.

$\mathrm{Na}$ mesma perspectiva inscreve-se a famosa "dança das cadeiras", reflexo da volatilidade dos políticos quanto aos partidos. Objeto de análises acadêmicas e jornalísticas, a troca de partido somente adquire sentido mais relevante quando representa a adesão a um projeto completamente diferente daquele do partido de origem. Nesse aspecto, é importante registrar que o senso comum (e mesmo de muitos analistas políticos) tende a confundir siglas partidárias com projetos políticos. Como não são sinônimos, a observação mais atenta às trocas de siglas acaba por demonstrar que tais câmbios respondem muito mais a adequações e interesses pessoais e/ou de grupos do que a mudanças substantivas no que diz respeito ao projeto.

Obviamente, tal desvio de atenção por parte do verdadeiro titular do poder - o cidadão - permite mantê-lo atento à periferia da política, enquanto a centralidade do processo decisório mantém-se preservado do foco de interesse. Nessa perspectiva, Gramsci (1988) identificou a "pequena" e a "grande" política. Segundo ele, enquanto a "pequena política" reflete conflitos e ajustes decorrentes da disputa pelo equilíbrio de forças existentes (sem ultrapassá-lo), a "grande política" responde pela estratégia e pela tática; pela conjuntura e pelo processo que envolve a política de estado e de governo.

A grande política, portanto, reflete o projeto de sociedade que organiza - explícita ou implicitamente - os partidos. A aparente irrelevância dos partidos preserva-os do debate macropolítico e, conseqüentemente, da escolha política eleitoral dos projetos em disputa. A prática institucional, entretanto, revela a unidade programática que a campanha e a visibilidade midiática oculta. Como demonstraram Figueiredo e Limongi, "a unidade de referência a estruturar os trabalhos legislativos são os partidos e não os parlamentares" (FIGUEIREDO \& LIMONGI, 1999, p. 20),
Mainwaring, Meneghello e Power, analisando os chamados partidos conservadores ${ }^{32}$ no Brasil, definiram como tais aqueles partidos que, ideologicamente, "tendem a apoiar políticas econômicas neoliberais e são mais conservadores quanto a questões como a segurança pública, o aborto $\mathrm{e}$ a moral familiar. E apesar dos autores reconhecerem as diferenças interestaduais, pontuam que, organizativamente, tais partidos são marcados por baixos níveis de disciplina partidária, pelo personalismo eleitoral e pela utilização regular de práticas clientelistas" (MAINWARING, MENEGHELLO \& POWER, 2000, p. 13).

No entanto, na medida em que tenho restrições à utilização de classificações tais como partido "conservador", "progressista", "de esquerda", "de centro", "de direita", "ideológico" ou "pragmático" 33 , por considerá-las muitos vagas e fluídas, não as utilizarei neste trabalho.

Entretanto, dados os limites deste artigo e à impossibilidade de analisar detidamente o programa de cada um dos partidos envolvidos, assim como a atuação dos parlamentares ao longo do período estudado, o que me permitiria sustentar aquele que considero o fundamento das diferenças interpartidárias - ou seja, o projeto de sociedade que estrutura o programa do partido -, ouso aqui proceder a outro corte diferenciador: a origem dos partidos políticos, tendo como referência o período de vigência da ditadura militar e, portanto, sua posição de resistência ou de sustentação quanto à ditadura.

Tal opção, obviamente, não impede a confluência de parlamentares de viés autoritário e a-democrático (no sentido lato da palavra) para o

32 Valendo-se de critérios definidos como pragmáticos, os autores identificaram os partidos conservadores brasileiros a partir da votação parlamentar e de pesquisas de opinião realizadas no Congresso. Dessa forma, segundo os autores, após 1985, são esses os partidos identificados como conservadores no cenário nacional: PDC, PMB, PMN, PP, PSC, PSL, PST, PTB, PTR, PDS, PFL, PL, PPB, PPR, PRN, Prona, PRP e PSD (MAINWARING, MENEGHELLO \& POWER, 2000, p. 31-32).

33 Em que pese a relevância de estudos sobre partidos feitos a partir de tais classificações, como a tese de doutoramento de André Singer, intitulada Esquerda e Direita no eleitorado brasileiro (SINGER, 2000) e o livro de Gláucio Ary Dillon Soares, A democracia interrompida (SOARES, 2001) 
MDB, considerando-se tanto a adesão de antigos udenistas, como a fragilidade do caráter de resistência/oposição do MDB matogrossense, conforme veremos em seguida, de acordo com estudos de Neves (2001).

O pertencimento ao MDB, entretanto, mesmo nas condições diferenciadas de Mato Grosso, implicava custos políticos aos seus membros. Nesse sentido, mesmo considerando que o período coberto por essa pesquisa contemple apenas os dois últimos anos da ditadura militar, a passagem pelo partido de oposição à ditadura possui um caráter contestatório nada desprezível; mesmo que em determinadas circunstâncias o pragmatismo político possa ser associado ao oportunismo eleitoral.

Posto isso, a análise dos parlamentos municipal e estadual, durante os anos de 1983 a 2004 permite-me confirmar observações iniciais. Em geral, as legislaturas foram compostas por bancadas originadas da Arena $^{34}$, do MDB e do PTB e seus desdobramentos partidários.

QUADRO 7 - ELEITOS PARAA CÂMARA MUNICIPAL DE CUIABÁ POR LEGISLATURA (1983-2004) (\%)

\begin{tabular}{|c|c|c|c|c|c|c|}
\hline PARTIDO & $\begin{array}{l}11^{\circ} \\
\text { (Eleiçöes } \\
1982 \text { ) }\end{array}$ & $\begin{array}{l}12^{\circ} \\
\text { (Eleiçöes } \\
1988 \text { ) }\end{array}$ & $\begin{array}{l}13^{\circ} \\
\text { (Eleiçőes } \\
1992 \text { ) }\end{array}$ & $\begin{array}{l}1^{\circ} \\
\text { (Eleiçöes } \\
1996 \text { ) }\end{array}$ & $\begin{array}{l}15^{\circ} \\
\text { (Eleiçöes } \\
2000 \text { ) }\end{array}$ & $\begin{array}{l}\text { MÉDIA } \\
\text { TOTAL }\end{array}$ \\
\hline PDS & 50 & - & 4,76 & - & - & 9,80 \\
\hline PMDB & 50 & 28,57 & 4,76 & 9,53 & 14,29 & 20,59 \\
\hline PTB & - & 33,34 & 19,05 & 14,28 & 9,52 & 15,68 \\
\hline PDT & - & 4,76 & 23,82 & 23,81 & - & 10,78 \\
\hline PSDB & - & - & 19,05 & 19,05 & 23,82 & 12,74 \\
\hline PPB & - & - & - & 4,76 & 4,77 & 1,96 \\
\hline PFL & - & 23,81 & 14,28 & 4,76 & 9,52 & 10,78 \\
\hline PT & - & 4,76 & - & 4,76 & 9,52 & 3,93 \\
\hline PPS & - & - & - & - & 9,52 & 1,96 \\
\hline PL & - & 4,76 & 9,52 & 4,76 & - & 3,93 \\
\hline PSB & - & - & - & 9,53 & 9,52 & 3,93 \\
\hline PDC & - & - & 4,76 & - & - & 0,98 \\
\hline PMN & - & - & - & 4,76 & 9,52 & 2,94 \\
\hline TOTAL & 100 & 100 & 100 & 100 & 100 & 100 \\
\hline
\end{tabular}

FONTE: Silveira (2007)

QUADRO 8 - SUPLENTES PARAA CÂMARA MUNICIPAL DE CUIABÁ POR LEGISLATURA (1983-2004) (\%)

\begin{tabular}{|c|c|c|c|c|c|c|}
\hline PARTIDO & $\begin{array}{l}11^{\circ} \\
\text { (Eleiçöes } \\
1982)\end{array}$ & $\begin{array}{l}12^{\mathrm{s}} \\
\text { (Eleiçőes } \\
1988 \text { ) }\end{array}$ & $\begin{array}{l}13^{\circ} \\
\text { (Eleiçöes } \\
1992 \text { ) }\end{array}$ & $\begin{array}{l}14^{3} \\
\text { (Eleiçöes } \\
1996)\end{array}$ & $\begin{array}{l}15^{\circ} \\
\text { (Eleiçöes } \\
2000 \text { ) }\end{array}$ & $\begin{array}{l}\text { MÉDIA } \\
\text { TOT AL }\end{array}$ \\
\hline PDS & 20 & - & - & - & - & 2,63 \\
\hline PMDE & 60 & 14,28 & 14,28 & 9,09 & - & 15,79 \\
\hline PTE & - & 14,28 & 28,58 & 9,09 & - & 10,52 \\
\hline PDT & - & 28,57 & 14,28 & 36,37 & - & 18,43 \\
\hline PSDB & - & - & 28,58 & 18,18 & 37,50 & 18,43 \\
\hline PFL & 20 & 42,87 & - & 9,09 & 12,50 & 15,79 \\
\hline PT & - & - & - & - & 25 & 5,26 \\
\hline PL & - & - & 14,28 & - & - & 2,63 \\
\hline $\mathrm{PSC}$ & - & - & - & - & 25 & 5,26 \\
\hline PMN & - & - & - & 9,09 & - & 2,63 \\
\hline PV & - & - & - & 9,09 & - & 2,63 \\
\hline TOTAL & 100 & 100 & 100 & 100 & 100 & 100 \\
\hline
\end{tabular}


Analisando a conformação partidária da Câmara Municipal de Cuiabá no período de extensos 22 anos, observa-se uma forte ascendência do PMDB, originário do MDB dos anos de vigência do bipartidarismo (1965-1979). Nada menos que $20,59 \%$ dos eleitos e $15,79 \%$ dos suplentes eram filiados ao partido no momento da eleição. Se ampliarmos um pouco mais o leque e considerarmos que o PSDB $(12,74 \%)$ surgiu de uma dissidência do PMDB (1988), sem grandes diferenças de fundo quanto ao projeto de sociedade, verificamos que nessa perspectiva encontraram-se $33,33 \%$ dos eleitos e $34,22 \%$ dos suplentes.

$\mathrm{Na}$ outra ponta, como contraposição ao MDB (PMDB) compareceu a ARENA, que com a reintrodução do pluripartidarismo gerou o PDS, que por sua vez deu origem ao PFL (atual DEM e anterior PPR e PPB).

Considerando-se essa vertente ideológica (PDS/ $\left.\mathrm{PFL} / \mathrm{PPB} / \mathrm{PL} / \mathrm{PDC}^{35} / \mathrm{PTB}\right)$, tem-se que a Câmara Municipal de Cuiabá foi composta por $43,13 \%$ dos eleitos do campo partidário cuja origem remete aos apoiadores da ditadura militar. Acrescentando-se os $31,57 \%$ dos suplentes, temos uma representação extremamente significativa desse campo.
Como segmento histórico ligado ao trabalhismo, temos o PTB, que por ocasião da reintrodução do pluripartidarismo e da disputa entre Leonel Brizola e Ivete Vargas pela direção da sigla (com a vitória desta), acabou por gerar o PDT, sob a direção de Brizola. Programaticamente, entretanto, o PTB acabou por aproximar-se do campo dirigido pelo PFL e seus aliados. O PDT, por sua vez, ocupou o espaço deixado pelo PTB das origens.

No campo do trabalhismo, tanto o PDT quanto o PT disputaram espaço, embora com projetos inicialmente - e substantivamente - diferenciados. Enquanto o PDT manteve-se na perspectiva populista de um trabalhismo atrelado ao caudilho (e ao Estado), sem perspectiva de classe, o $\mathrm{PT}^{36}$ surgiu como um partido classista e emancipacionista por força da organização autônoma dos próprios trabalhadores, em plena ditadura militar.

Dessa forma, enquanto o PDT contou com $10,78 \%$ dos eleitos e $18,43 \%$ dos suplentes, o PT não atingiu, sequer, $4 \%$ dos eleitos e $3 \%$ dos suplentes.

A ALMT, por sua vez, não teve conformação muito diferente daquela registrada no Parlamento Municipal.

QUADRO 9 - ELEITOS PARA A ASSEMBLÉIA LEGISLATIVA DO ESTADO DE MATO GROSSO POR LEGISLATURA (1983-2002) (\%)

\begin{tabular}{|c|c|c|c|c|c|c|}
\hline PARTIDO & $\begin{array}{l}10^{\circ} \\
\text { (Eleiçöes } \\
1982)\end{array}$ & $\begin{array}{l}11^{\circ} \\
\text { (Eleiçöes } \\
1986)\end{array}$ & $\begin{array}{l}12^{\circ} \\
\text { (Eleiçöes } \\
1990 \text { ) }\end{array}$ & $\begin{array}{l}13^{\circ} \\
\text { (Eleiçőes } \\
\text { 1994) }\end{array}$ & $\begin{array}{l}14^{\circ} \\
\text { (Eleiçöes } \\
1998 \text { ) }\end{array}$ & $\begin{array}{l}\text { MÉDIA } \\
\text { TOTAL }\end{array}$ \\
\hline PMDB & 45,83 & 58,33 & 12,50 & 13,04 & 16,67 & 29,41 \\
\hline PFL & - & 37,50 & 45,83 & 26,09 & 20,83 & 26,05 \\
\hline PDS & 54,17 & - & 8,33 & - & - & 12,60 \\
\hline PSDB & - & - & - & 8,69 & 25 & 6,73 \\
\hline PL & - & 4,17 & 4,17 & 17,39 & 8,33 & 6,73 \\
\hline PDT & - & - & 8,33 & 17,39 & - & 5,04 \\
\hline PT & - & - & 4,17 & 4,35 & 8,33 & 3,36 \\
\hline PTE & - & - & 4,17 & - & 8,33 & 2,52 \\
\hline PPB & - & - & - & 4,35 & 4,17 & 1,68 \\
\hline PSB & - & - & - & 4,35 & 4,17 & 1,68 \\
\hline PRN & - & - & 8,33 & - & - & 1,68 \\
\hline PPS & - & - & - & - & 4,17 & 0,84 \\
\hline PDC & - & - & 4,17 & - & - & 0,84 \\
\hline PMN & - & - & - & 4,35 & - & 0,84 \\
\hline TOTAL & 100 & 100 & 100 & 100 & 100 & 100 \\
\hline
\end{tabular}

FONTE: Silveira (2007) 
QUADRO 10 - SUPLENTES PARA A ASSEMBLÉIA LEGISLATIVA DO ESTADO DE MATO GROSSO POR LEGISLATURA (1983-2002) (\%)

\begin{tabular}{|c|c|c|c|c|c|c|}
\hline PARTIDO & $\begin{array}{l}10^{\circ} \\
\text { (Eleiçöes } \\
1982)\end{array}$ & $\begin{array}{l}11^{\circ} \\
\text { (Eleiçöes } \\
1986)\end{array}$ & $\begin{array}{l}12^{3} \\
\text { (Eleiçöes } \\
1990)\end{array}$ & $\begin{array}{l}13^{\circ} \\
\text { (Eleiçöes } \\
1994)\end{array}$ & $\begin{array}{l}14^{\circ} \\
\text { (Eleiçőes } \\
1998)\end{array}$ & $\begin{array}{l}\text { MÉDIA } \\
\text { TOTAL }\end{array}$ \\
\hline PFL & - & 50 & 26,66 & 28,57 & 18,75 & 24,08 \\
\hline PMDE & 12,50 & 37,50 & 13,33 & - & 18,75 & 16,67 \\
\hline PDS & 87,50 & - & 6,67 & - & - & 14,82 \\
\hline PDT & - & 12,50 & 20 & 28,57 & 6,25 & 12,97 \\
\hline PSDB & - & - & - & - & 31,25 & 9,26 \\
\hline PL & - & - & 20 & - & - & 5,55 \\
\hline PMN & - & - & - & 28,57 & - & 3,70 \\
\hline $\mathrm{PSC}$ & - & - & - & 14,29 & 6,25 & 3,70 \\
\hline PTE & - & - & 6,67 & - & - & 1,85 \\
\hline PDC & - & - & 6,67 & - & - & 1,85 \\
\hline PSD & - & - & - & - & 6,25 & 1,85 \\
\hline PSB & - & - & - & - & 6,25 & 1,85 \\
\hline PPB & - & - & - & - & 6,25 & 1,85 \\
\hline TOTAL & 100 & 100 & 100 & 100 & 100 & 100 \\
\hline
\end{tabular}

FONTE: Silveira (2007)

O campo historicamente identificado com a resistência democrática durante o período militar (PMDB e PSDB) alcançou 36,14\% durante os 20 anos estudados. A suplência alcançou 25,93\%. No campo daqueles que deram sustentação à ditadura militar (PDS, PFL, PL, PTB, PPB, PRN e PDC), a supremacia foi incontestável: 52,10\%. Considerando a suplência, também aí detiveram ascendência: $50 \%$.

No campo do trabalhismo - respeitadas as suas diferenças - temos o PDT com 5,04\% dos eleitos e o PT com 3,36\%. A suplência foi mais generosa com o PDT, que chegou a $12,97 \%$, mas não garantiu nenhuma atuação ao PT.

Tanto na conformação da Câmara Municipal de Cuiabá quanto da Assembléia Legislativa do Estado de Mato Grosso, o PMDB, isoladamen-

ra a ruptura permita identificar contextos históricos, o processo de construção é anterior ao momento de corte. Nesse sentido, podemos identificar, historicamente, um partido com forte compromisso socialista e cuja transformação de projeto assumiu forma com a expulsão de tendências genuinamente socialistas, em 1992. A partir daí passou a viger um projeto de inspiração social-democrata, nos moldes da experiência européia. O processo de transformação petista de social-democrata para uma transição para o projeto neoliberal assumiu forma pública com a expulsão de deputados federais e da Senadora Heloísa Helena, em 2003. te, alcança superioridade eleitoral: $20,59 \%$ e $29,41 \%$, respectivamente.

Considerando, entretanto, a representação partidária a partir da percepção eleitoral do eleitor (mesmo que difusa e contraditória), podemos analisar a configuração dos parlamentos municipal e estadual tendo como referência a contraposição entre aqueles que deram sustentação ao regime militar e aqueles cuja trajetória é marcada pela resistência democrática.

Nessa perspectiva, podemos considerar que o campo representativo de partidos ${ }^{37}$ que - direta ou indiretamente - deram sustentação a governos autoritários foi dominante na ALMT $(52,94 \%) \mathrm{e}$ um pouco menos referendado na CMC $(46,07)$. Em contraposição, a CMC (Gráfico 3) registrou maior representatividade de partidos oriundos da luta de resistência democrática $(53,93 \%)$, que obtiveram 47,06\% na ALMT (Gráfico 4).

37 Incluem-se no campo democrático: PMDB, PDT, PSDB, PT, PSB e PPS. Registre-se que o PPS foi originado do PCB, em 1992. No campo autoritário incluem-se: PDS, PTB, PPB, PFL, PL, PDC, PRN e PMN. Estes três últimos foram concluídos tanto pela proeminência de figuras públicas ligadas à Arena e ao PDS, quanto pelo discurso de viés autoritário que perfaz o Manifesto do Partido de Mobilização Nacional, bastante articulado com aquele proveniente do Prona, cuja formação remete à ascendência militar. 
GRÁFICO 3 -PERFIL IDEOLÓGICO PARTIDÁRIO DA CÂMARA MUNICIPAL DE CUIABÁ - 5 LEGISLATURAS (1983-2004) - ELEITOS E SUPLENTES
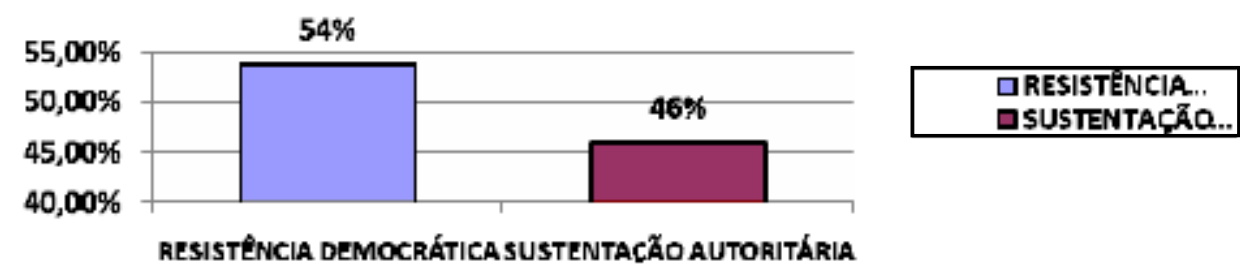

FONTE: Silveira (2007)

NOTA: Universo de 140 vereadores

GRÁFICO 4 -PERFIL IDEOLÓGICO PARTIDÁRIO DAASSEMBLÉIA LEGISLATIVA - 5 LEGISLATURAS (19832002) - ELEITOS E SUPLENTES

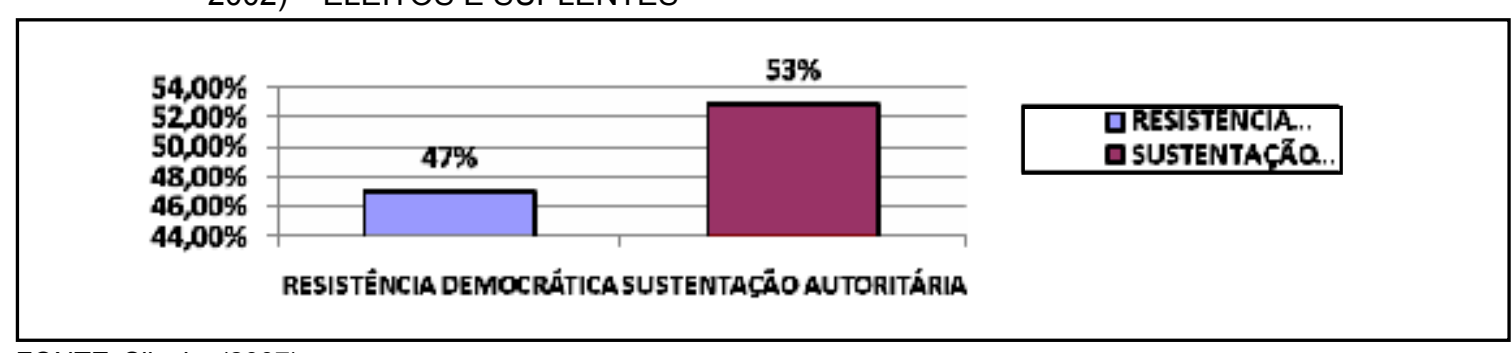

FONTE: Silveira (2007).

NOTA: Universo de 173 deputados.

\section{TRAJETÓRIA POLITICO-PARTIDÁRIA}

De acordo com Maria Neves, "o sistema bipartidário Arena-MDB, no qual se assentou o autoritarismo, expressou-se em Mato Grosso como um projeto continuísta das elites do pluripartidarismo" (NEVES, 2001, p. 269). Segundo a autora, o MDB, localmente, era um partido sem transparência ideológica ou consistência oposicionista e a Arena um partido majoritário, que lhe permitiu, inclusive, capturar com eficiência o voto opositor, especialmente por meio da cisão interna da Arena, polarizada entre Arena 1 e Arena 2 (idem, p. 271)

Tal hegemonia partidária, segundo Neves, tem origem especialmente no processo de recomposição das forças políticas no contexto de bipartidarismo. Enquanto a Arena absorveu a esmagadora maioria das lideranças políticas (analisadas, especialmente, aquelas com mandato), o MDB regional sofreu com a conjugação de dois aspectos: de um lado, "abrigou egressos da UDN"38, o que, segundo a autora, "contribuiu para

38 A política matogrossense, segundo Neves, foi marcada pela hegemonia bipartidária, durante o período pluripartidário anterior ao golpe militar, pelos partidos PSD dificultar a transparência da identificação emedebista". (idem, p. 292, grifos do original); de outro, o MDB estruturou-se, fundamentalmente, a partir das bases do PTB, que no início dos anos 1960 "apenas começara a afirmar-se como a terceira força eleitoral no estado", e, além disso, não havia se constituído em uma "oposição de fato no período pluripartidário, na medida em que tinha uma vasta história de alianças definidas ao nível regional, e às vezes municipal, com o PSD e até com a UDN" (idem, p. 300, grifos do original).

É sobre essa tradição política eleitoral que podemos compreender o perfil majoritariamente conservador da ALMT e, em menor medida, da CMC.

O acompanhamento da trajetória partidária ${ }^{39}$ dos parlamentares corrobora o quadro acima analisado, na medida em que a maioria dos deputados

e UDN, sendo o PTB um partido pouco alicerçado regionalmente.

39 Na mesma perspectiva das dificuldades enfrentadas para o levantamento dos demais dados, os que dizem respeito à trajetória partidária foram singularmente dificultados. Tanto os eventuais documentos encontrados na CMC e na ALMT muitas vezes são omissos quanto a essas informações, ou quando as contêm são irregulares ou por 
e vereadores (eleitos e suplentes) teve alguma passagem pelos principais partidos que conformaram $\mathrm{a}$ análise anterior.

A opção pelo acompanhamento da adesão partidária ou mesmo "passagem" pelos partidos revelou-se interessante por servir de referência para acompanhar a trajetória dos parlamentares. Não por acaso, não se observa índices representativos de filiação a partidos com forte identificação ideológica classista ou a partidos sem capital eleitoral e, portanto, capazes de abrigar candidaturas ascendentes, mas dependentes de coeficiente eleitoral.

Nesse sentido, considerando as legislaturas, o Gráfico 5 é expressivo da preferência partidária dos deputados estaduais.

GRÁFICO 5 - PARTIDOS POLÍTICOS PELOS QUAIS PASSARAM OS DEPUTADOS ESTADUAIS NA SUA TRAJETÓRIA POLÍTICA PARTIDÁRIA - 10ª̀ 14ª LEGISLATURAS (1983-2002)

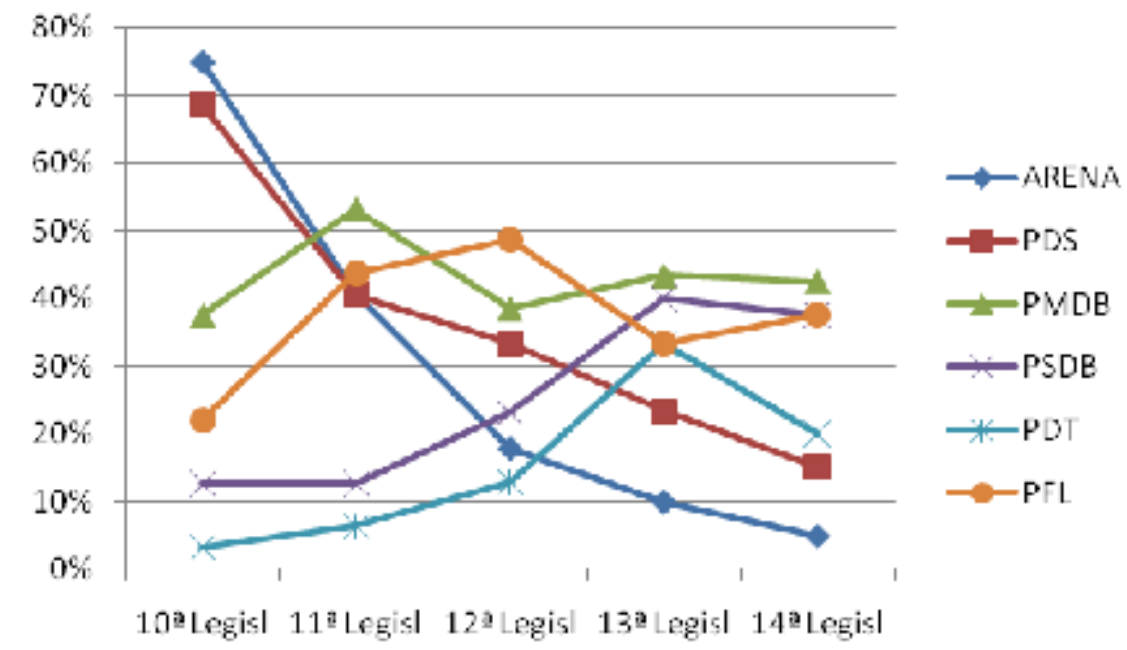

FONTE: Silveira (2007)

Resumidamente, observado todo o período estudado, o PMDB foi o partido com maior número de parlamentares filiados (permanente ou por período reduzido), alcançando $42,77 \%$. O PFL atingiu $37,57 \%$; o PDS $35,26 \%$ e a Arena $28,32 \%$. O PSDB registrou $25,43 \%$.

Na Câmara Municipal, também foi o PMDB o partido com maior adesão por parte dos vereadores, consideradas as passagens: $44,29 \%$; o PSDB totalizou $41,43 \%$; o PDT e o PTB atingiram $26,43 \%$ cada um e o PFL $25,71 \%$.

demais econômicas. Por outro lado, quando do acesso direito aos próprios parlamentares (seja via entrevista, questionário ou mesmo entrega de currículo), esses não costumam informar todos os partidos pelos quais passaram, muito menos a ordem de filiação partidária. Essa análise, portanto, foi elaborada a partir dos dados disponíveis e das informações concedidas pelos entrevistados.
Assim, em que pese o perfil partidário mais democrático ${ }^{40}$ (conforme o Gráfico 6), o elemento novo é o crescimento do PPS, alcançando $15 \%$ (na média de todo período), assim como o crescimento do PT, especialmente na $15^{\mathrm{a}}$ Legislatura: $17,24 \%$. Porém, considerado todo o período estudado na Câmara, a média do partido totalizou apenas $6,43 \%$.

Na medida em que esses dados correspondem ao partido com maior número de adesões durante o período pesquisado, não captaram o crescimento eleitoral do PDSB nas eleições de 1998 (ALMT) e 2000 (CMC), o qual obteve maior votação (considerando-se tanto eleitos quanto suplentes), conforme quadros apresentados anteriormente. Nesse aspecto, importa registrar a reeleição tanto de

40 Essa classificação, como já foi dito, reflete e responde tão somente aos critérios de recorte da história brasileira recente. 
Dante Martins de Oliveira (PDSB) para o Governo de Mato Grosso quanto de Roberto França (PSDB) para a Prefeitura de Cuiabá, assim como a habitual migração partidária que acompanha os partidos que estão no exercício do poder e que gozam de relativa legitimidade social.

\section{GRÁFICO 6 - PARTIDOS POLÍTICOS PELOS QUAIS PASSARAM OS VEREADORES NA SUA TRAJETÓRIA POLÍTICA PARTIDÁRIA - $11^{\mathrm{a}}$ À $15^{\mathrm{a}}$ LEGISLATURAS (1983-2004)}

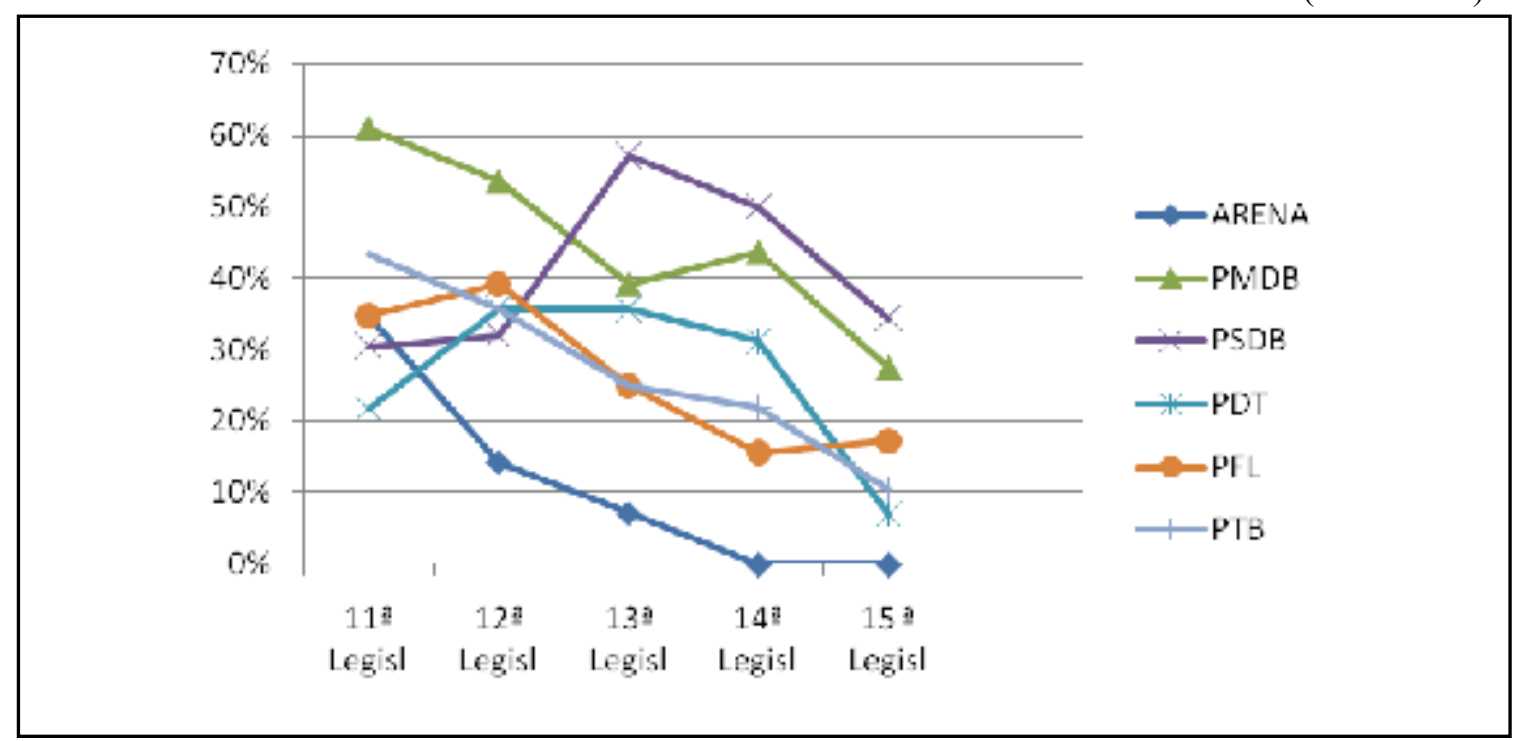

FONTE: Silveira (2007)

Dessa forma, se isoladamente os partidos são registros indicativos da adesão dos parlamentares a determinadas perspectivas históricas ou ideológicas, assim como de projetos de sociedade, pertinente também é verificar quais as trajetórias político-partidárias mais comuns entre parlamentares municipais e estaduais.

Na medida em que várias combinações são possíveis quando se trata da filiação partidária, a título de registro foi possível identificar, na Câmara $\mathrm{Mu}$ nicipal, que a trajetória ${ }^{41}$ mais comum perfaz o seguinte trânsito: PMDB $>$ PDT $>$ PSDB $(4,29 \%)$ e PMDB $>$ PTB $>$ PFL (3,57\%). Este também foi o percentual alcançado, isoladamente, pelo PT. Na ALMT, por sua vez, a seqüência Arena $>$ PDS e Arena $>$ PDS $>$ PFL alcançaram 6,94\% cada uma. O PMDB, isoladamente, totalizou 5,78\%.

41 Na medida em que foram pesquisados 213 parlamentares e que há tradição quanto à troca de partidos, permitindo passagens rápidas por algumas siglas, a construção de um perfil mais representativo foi inviável. Considerando que as trajetórias são muitas e que seguem a mesma seqüência histórica, apesar de muitas vezes refletirem os mesmos partidos, foi impossível a totalização de números mais expressivos, mesmo que do ponto de vista programático tenham sido raras as mudanças partidárias.
Como tais índices não me permitem extrair nenhuma conclusão, somente posso realçar que as verdadeiras matizes ideológicas transcendem esse recorte histórico de sustentação versus resistência à ditadura, posto que a oposição ao regime militar nada revela sobre o caráter (conteúdo e abrangência) da democracia defendida pelo partido em questão.

O redimensionamento da análise dos partidos políticos, a partir da centralidade dos projetos, demanda uma análise do programa e da atuação partidária, que, como já declarei anteriormente, não é objeto deste artigo. Esse redimensionamento, entretanto, permite-nos compreender, sem estranhamentos, porque trajetórias que caminham da Arena para o PSB (Arena $>$ PDS $>$ PFL $>$ PSB) ou para o PPS (Arena $>$ PDS $>$ PFL $>$ PPS) não refletem, propriamente, inconsistência ideológica. Porém, na mesma perspectiva, exigiria esforço de análise para explicar o trânsito entre a Arena e o PT, dependendo do período histórico em que tais passagens ocorrem.

Por fim, cabe observar que a nomenclatura da sigla partidária não é indicativa do projeto do partido. Basta verificar as metamorfoses do PPS, que do PCB transformou-se em ninho de grandes 
empresários $^{42}$ que, obviamente, de socialistas nada têm. Nessa mesma perspectiva cabe refletir sobre a Social-Democracia do PSDB, o Socialismo do PSB e a prevalência dos interesses dos trabalhadores por parte do PT na atualidade.

\section{O PARLAMENTO COMO SINÔNIMO DE VIVER DA POLÍTICA}

Max Weber, no seu clássico A Política como Vocação (WEBER, 1968), identificou dois tipos de políticos: aqueles que vivem para a política e aqueles que vivem da política. Os primeiros não dependem financeiramente da política e, assim, dedicam-se a ela por razões de princípio; os segundos vivem dos recursos que extraem da própria atividade política. A maioria dos parlamentares pesquisados, entretanto, parece conjugar, sem conflitos, ambas as situações; mas o viver da política fazendo dessa atividade uma profissão ${ }^{43}$ - subordina o caráter de princípios do viver para a política.

Observando-se o universo dos 119 deputados estaduais que passaram pela ALMT durante o período pesquisado e excluindo-se aqueles que foram eleitos apenas uma vez $(26,89 \%)$ ou foram suplentes uma única vez $(18,49 \%)$, mais de $50 \%$ dos parlamentares $(54,62 \%)$ obtiveram êxito em manterem-se ativos como representantes legislativos.

Também nessa empreitada várias composições são possíveis. Desde aqueles que foram eleitos duas vezes $(7,56 \%)$ ou três vezes consecutivas $(5,04 \%)$, àqueles que foram suplentes duas vezes consecutivas $(5,89 \%)$ ou eleitos três vezes, sendo uma vez como suplente, ou tantas outras combinações possíveis. Porém, considerando-se o quadro geral, pode-se inferir que há uma significativa estabilidade no quadro de parlamentares, sendo a recondução (ou sua tentativa) um objetivo permanentemente renovado. Isso, em especial, porque a não recondução consecutiva ao poder Legislativo não significa que o político não tenha disputado - e assumido - o poder em outras instâncias estatais ou mesmo em outro poder. Esse é o caso de parlamentares que, por exemplo, disputam a Prefeitura do interior do estado, ou daqueles que se afastam para assumir o Secretariado ou mesmo a direção de órgãos públicos. Ou mesmo daqueles que não alcançam os votos necessários para a recondução imediata, mas retornam depois.

Considerando apenas a dicotomia recondução/ renovação, a partir do número de parlamentares que assumiram o poder em algum momento do mandato (ou seja, eleitos e suplentes que assumiram), temos um quadro cuja média aponta para um percentual de $38,29 \%$ de recondução na ALMT e $34,06 \%$ na $\mathrm{CMC}$, consideradas todas as legislaturas.

Na Câmara Municipal (Gráfico 7), o quadro revela uma tendência de crescimento de recondução: de $17,39 \%$ na $11^{\text {a }}$ para $48,27 \%$ na $15^{\text {a }}$ Legislatura.

GRÁFICO 7 -RENOVAÇÃO E REELEIÇÃO DACÂMARA MUNICIPAL DE CUIABÁ - $11^{\mathrm{a}} \mathrm{À} 15^{\mathrm{a}}$ LEGISLATURAS (1983-2004)

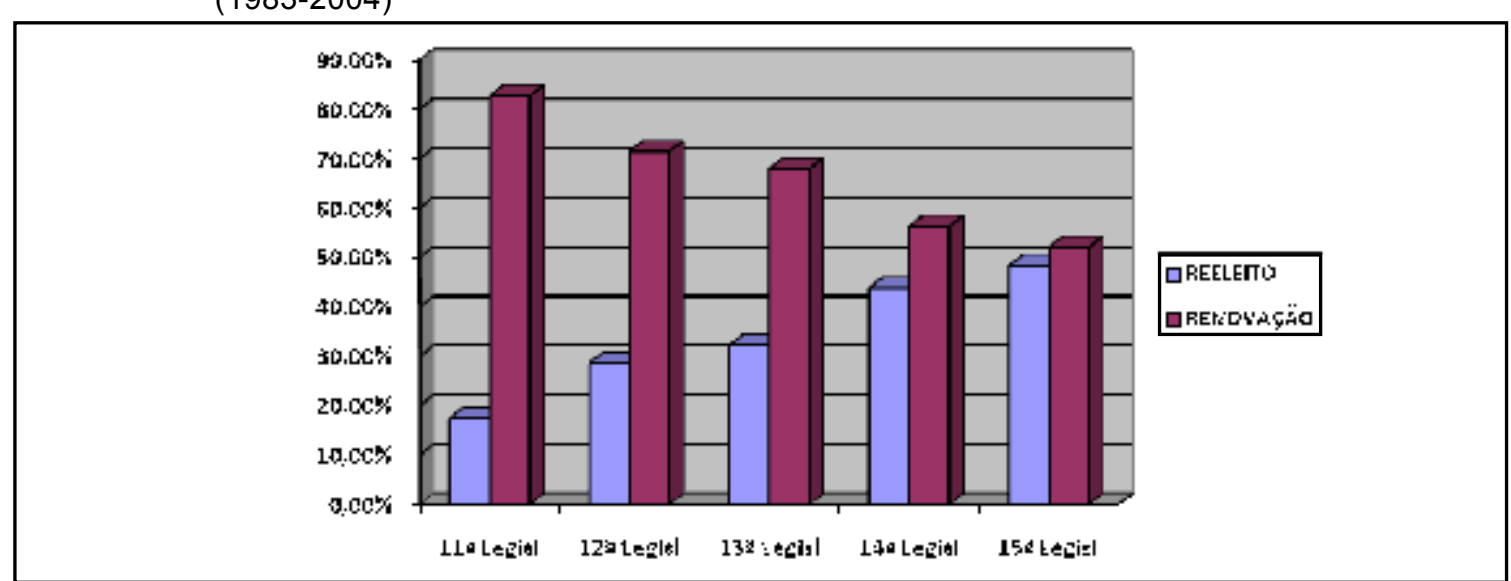

FONTE: Silveira (2007)

NOTA: Universo de 94 vereadores.

42 Não por acaso, o maior empresário de soja do país, Blairo Maggi, foi eleito pelo PPS, em 2002, para o governo do estado de Mato Grosso.
43 Não por acaso, dois entrevistados informaram como sua profissão ser "político". Outros, mais discretos, preferem indicar sua formação acadêmica como atividade profissional, embora não a exerça há algum tempo. 
No caso da ALMT, ao contrário, não é possível acompanhar uma linha ascendente de recondução ao poder. Considerando, entretanto, a $10^{\mathrm{a}}$, a $11^{\mathrm{a}}$ e a $13^{\mathrm{a}}$ legislaturas, é possível identifi- car percentuais superiores a $40 \%$. Porém, a renovação acentuada ocorrida na $12^{\mathrm{a}}(25,64 \%)$ e na $14^{\mathrm{a}}(35 \%)$ legislaturas forçaram a média para baixo, como podemos observar no Gráfico 8.

GRÁFICO 8 - RENOVAÇÃO E REELEIÇÃO DAASSEMBLÉIA LEGISLATIVA DE MATO GROSSO - $10^{\mathrm{a}}$ À $14^{\mathrm{a}}$ LEGISLATURAS (1983-2002)

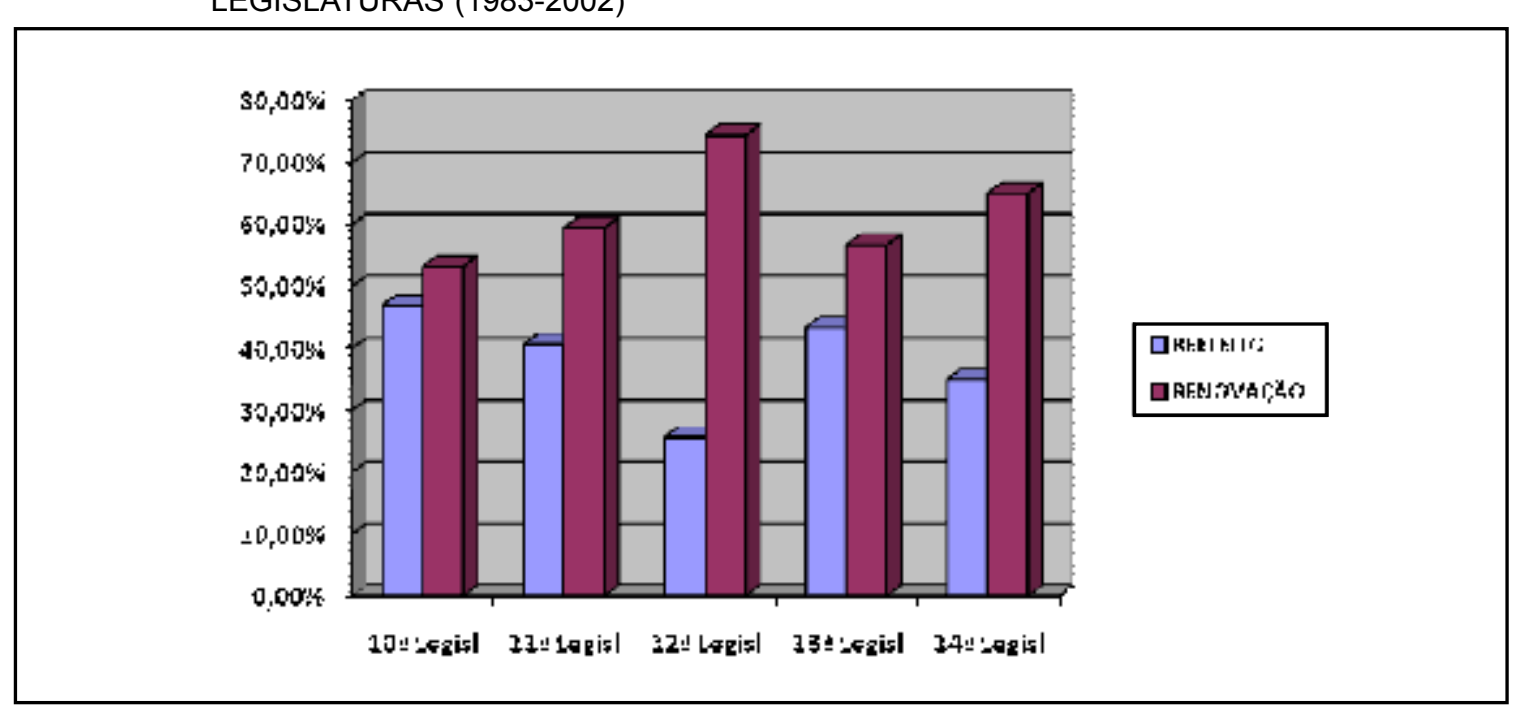

FONTE: Silveira (2007).

NOTA: Universo de 119 deputados.

Entretanto, se acrescentarmos a esses números o fato de que muitos parlamentares movimentam-se em direção a outros poderes (poder Executivo), outras esferas (municipal, estadual, federal) e também outras formas de participação nos espaços decisórios da estrutura estatal, observaremos que o percentual de conservação parlamentar é bastante significativo.

Tal realidade, embora demonstre adequada a diferenciação elaborada por Weber entre os que vivem da política e aqueles que vivem para a política, também demonstra que aqueles que passam a viver da política não o fazem porque não dispõem de recursos. Mas, ao contrário, passam a viver da política como meio preferencial de acumular patrimônio particular, como veremos adiante, a partir da avaliação das declarações de bens disponíveis.

Analisando, inicialmente, a atividade política institucional, constatei que a vereança constituise em um importante trampolim para o exercício do poder nas instâncias estatais. Seja por meio do processo eleitoral (para cargos legislativos ou executivos), seja por meio das relações de barganha que alcançam maior consistência e chances de êxito conforme o capital eleitoral e ascendência na estrutura partidária desfrutadas pelo político.

Dessa forma, o histórico político institucional dos deputados estaduais (Gráfico 9), ratifica a importância dos espaços locais como mecanismo de ascensão eleitoral. Não por acaso, como vimos acima, a tendência dos parlamentares da ALMT é disputar a reeleição ou, então, consolidar espaços nas secretarias de estado, empresas ou órgãos públicos ou, ainda, disputar as eleições para a Câmara Federal ou ao Senado. Também constitui área de interesse a disputa pela Prefeitura Municipal, seja da capital seja do interior. O retorno à Câmara Municipal não se apresenta como alternativa comum, revelando-se mais claramente nos casos em que a disputa pela reeleição não obteve êxito e as demais opções institucionais de poder não se apresentam satisfatórias para alimentar (e aumentar) o capital eleitoral para as próximas eleições. 


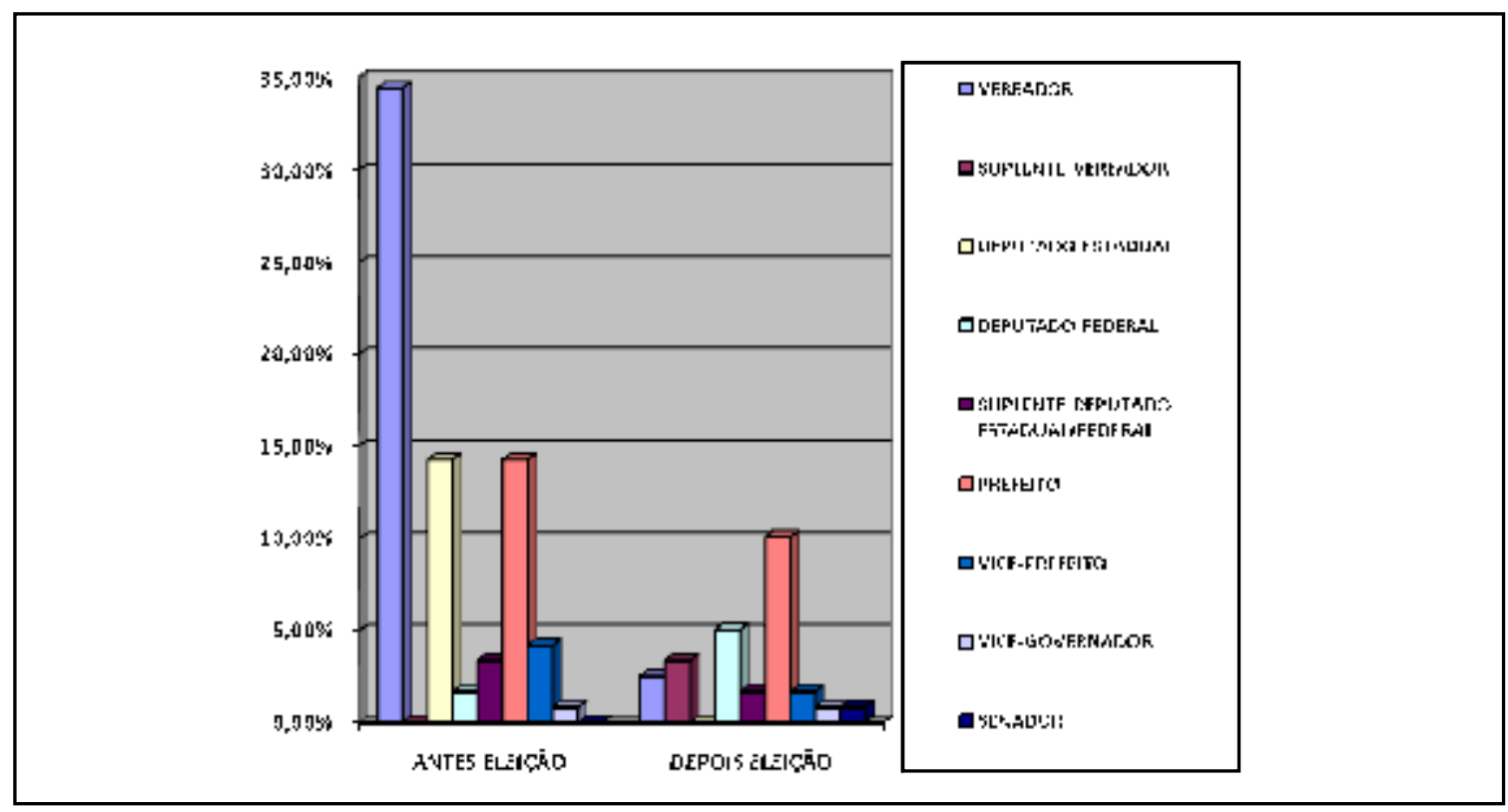

FONTE: Silveira (2007)

NOTA: Universo de 119 deputados.

Na Câmara de Vereadores (Gráfico 10), a conjugação de boas articulações políticas e midiáticas, assim como visibilidade popular e práticas assistenciais tendem a aumentar, substancialmente, a performace eleitoral, como já disse acima, permitindo vôos mais altos. Nessas condições, o Parlamento Estadual transforma-se no caminho mais comum para alguns políticos, que preferem arriscar-se em outras esferas de poder, as quais asseguram, também, maior poder e, portanto, maior capital eleitoral.
Nessas condições, percebe-se, claramente, que a experiência no Parlamento constitui-se em uma importante oportunidade para profissionalizar-se como político, intercalando funções executivas e legislativas. Conseqüentemente, quanto maior a capacidade de manter-se à frente dos espaços públicos (principalmente os eletivos), maior também é a capacidade de ascendência sobre outros políticos e partidos.

GRÁFICO 10 - TRAJETÓRIA POLITICA VEREADORES CÂMARA MUNICIPAL DE CUIABÁ - $11^{\text {a }}$ À $15^{\mathrm{a}}$ LEGISLATURA (1983-2004)

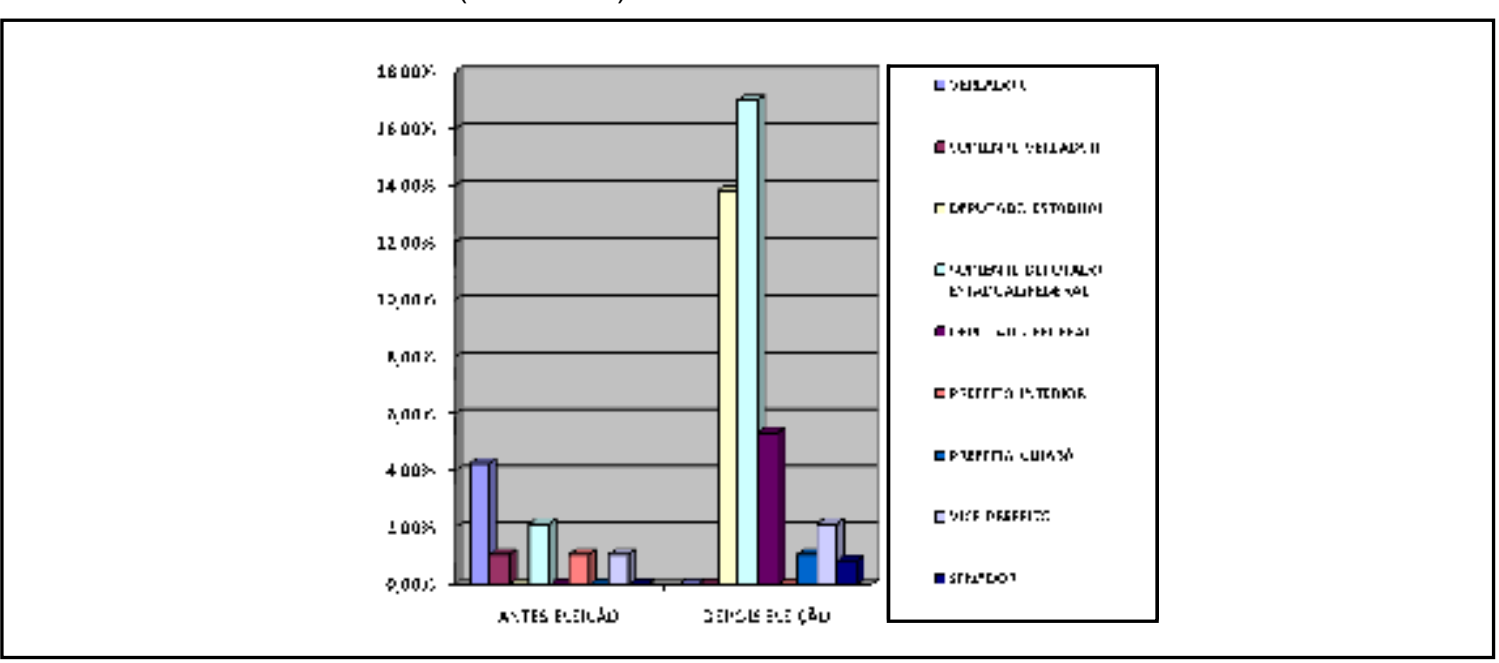

FONTE: Silveira (2007).

NOTA: Universo de 94 vereadores. 
Nessa perspectiva, a ocupação de espaços de poder é decisiva. Afinal, se o capital eleitoral é a condição e também a finalidade de manter-se em evidência, exercer o secretariado (municipal ou estadual), dirigir empresas públicas, participar do processo decisório garantido pela mesa diretora (seja da Câmara seja da Assembléia), ou, ainda, deter cargos diretivos na estrutura partidária, constituem-se em importantes instrumentos de consagração política e, portanto, de sobrevivência na política.

Essas condições estão espelhadas nos Gráfi$\cos 10$ (CMC) e12 (ALMT), nos quais se observam, claramente, os movimentos ascendentes construídos no processo posterior ao período eleitoral. Abertas as portas da institucionalidade, especialmente por meio da vereança, a dialética do poder vai tecendo suas amarras.

GRÁFICO 11 - TRAJETÓRIA POLÍTICA VEREADORES CÂMARA MUNICIPAL DE CUIABÁ - $11^{\mathrm{a}}$ A $15^{\mathrm{a}}$ LEGISLATURA (1983-2004)

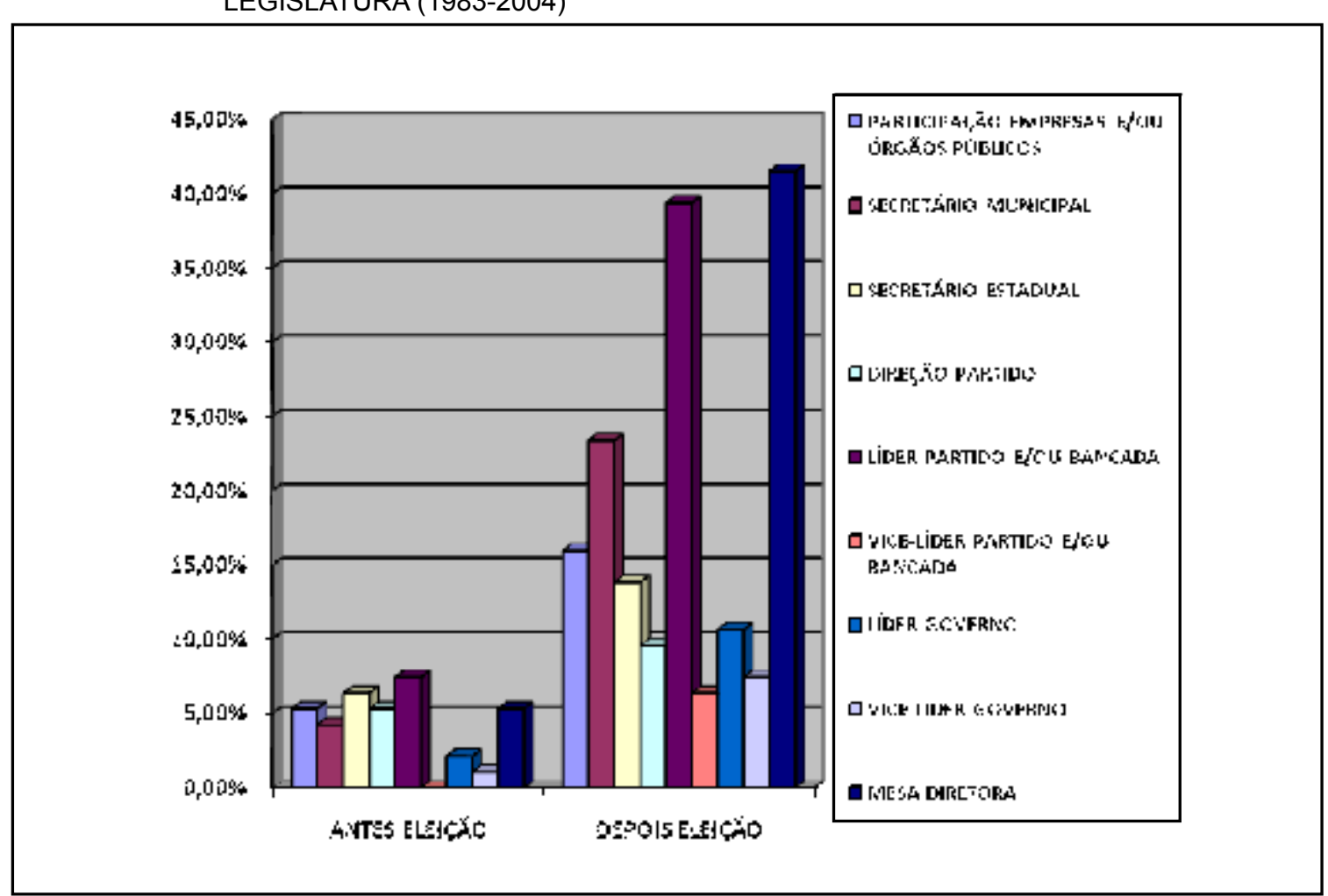

FONTE: Silveira (2007)

NOTA: Universo de 94 vereadores.

A análise dos parlamentares que passam a freqüentar com espantosa regularidade as esferas do poder instituído precisa considerar, ainda, a quantidade de vezes que o mesmo parlamentar exercer determinado cargo, ou mostra-se multifuncional, isto é, capaz de responder por diferentes secretarias.

Considerando o secretariado estadual e municipal, $8,51 \%$ dos vereadores alçados a condição de secretários exerceram essa atividade tanto na esfera municipal quanto estadual. No caso dos deputados estaduais, foram $7,56 \%$.
No caso da mesa diretora (da Câmara ou da Assembléia) representa um sobre-poder nada desprezível para o exercício cotidiano das atividades parlamentares. Aqueles eleitos pelos seus pares para comporem a mesa diretora (especialmente por meio de acordos partidários), para o mandato de um biênio, têm assegurado um conjunto de prerrogativas que vão desde a substituição do titular do poder Executivo até a instituição da dinâmica de trabalhos, o que significa, inclusive, a capacidade de agilizar ou de criar obstáculos a seu andamento. 

2004)

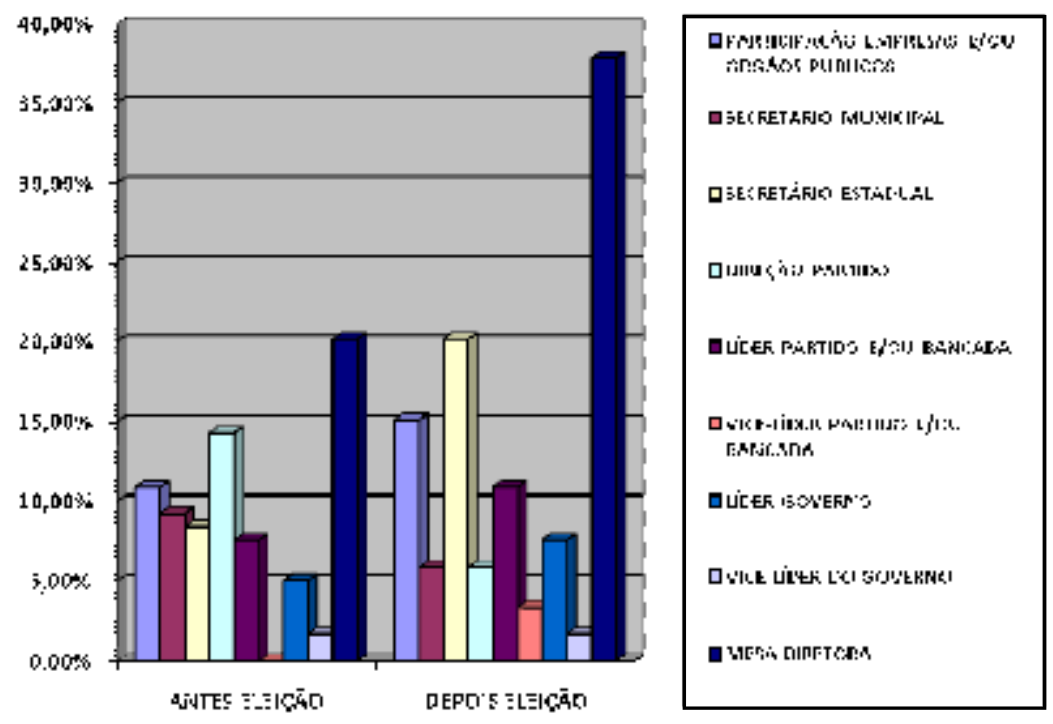

FONTE: Silveira (2007)

NOTA: Universo de 119 deputados.

Ainda sobre a política institucional como meio de vida e profissionalização, há que se registrar a utilização do Tribunal de Contas do Estado de Mato Grosso, como espaço privilegiado de poder e fonte de recursos materiais. Considerando apenas o período estudado, dos 29 deputados estaduais que exerceram algum cargo em empresa ou órgão público, nada menos que nove deles foram nomeados para o TCE-MT.

De acordo com lista divulgada pelo próprio Tribunal, os conselheiros - cargos vitalícios, com salário de R \$ 22 111,25 (LOTACIONOGRAMA DO TCE EXPÕE O NEPOTISMO, 2007) - podem nomear 20 assessores, sem necessidade de concurso público, o que garante aos conselheiros uma ampla confraternização familiar com dinheiro público.

Porém, tão ou mais grave do que a "orgia nepotista" é a nomeação de políticos com extensa lista de processos civis e criminais em andamento, acusados de improbidade administrativa, peculato, formação de quadrilha e lavagem de dinheiro ${ }^{44}$. Ainda mais se considerarmos que a prin-

44 Segundo denúncias do Ministério Público (MP) de Mato Grosso, o Conselheiro Humberto Bosaipo (DEM) desviou cerca de $\mathrm{R} \$ 97$ milhões em recursos públicos, es- cipal atribuição do TCE é, justamente, o controle das finanças públicas, pois, de acordo com sítio de internet do Tribunal, trata-se de uma "instituição pública de controle externo responsável em zelar pelo patrimônio público e fiscalizar a aplicação dos recursos".

Por fim, valendo-me das declarações de bens ${ }^{45}$ dos candidatos entregues ao TRE-MT, foi possível estabelecer alguns parâmetros de referência para dimensionar o coroamento patrimonial de "tanto empenho" institucional, especialmente se

pecialmente quando esteve à frente da Mesa Diretora da ALMT. Ainda de acordo com o MP de Mato Grosso, o Conselheiro responde a 50 ações públicas e 15 criminais.

45 Em que pese todo o esforço feito, não foi possível conseguir todas as declarações a partir de 1998 (quando foi instituída a obrigatoriedade) até 2006, especialmente dos candidatos municipais, posto que essas declarações são guardadas nos cartórios eleitorais; que estabelecem algumas dificuldades adicionais para o acesso. No caso das Declarações dos candidatos estaduais e federais, dadas as dificuldades operacionais do TRE-MT, tive que me valer dos portais www.excelencias.org.br e de www.politicosdobrasil.com.br (acesso em 10.ago.2009). Nesse sentido, agradeço especialmente às indicações fornecidas pelo jornalista Fernando Rodrigues, da Folha de São Paulo. 
considerada a hegemonia neoliberal, que sataniza o Estado e tudo que remeta à política e às políticas públicas.

De acordo com levantamento realizado em junho de 2007, o salário do Vereador de Cuiabá corresponde a R $\$ 150,00$, o qual é acrescido de verba indenizatória de $\mathrm{R} \$ 4000,00$, totalizando, assim, R\$ 11 150,00 mensais. O Deputado Estadual, por sua vez, recebe $\mathrm{R} \$ 9.540,00$, acrescido de verba indenizatória no valor de $\mathrm{R} \$ 15000,00$, o que garante um montante mensal de $\mathrm{R} \$ 24$ 540,00. Entretanto, quanto confrontei as Declarações de Bens e Direitos de 1998, 2002 e 2006, deparei-me com um incremento patrimonial verdadeiramente excepcional de alguns deputados. Variações que, evidentemente, não podem ser explicadas pelos salários recebidos, ainda mais se consideradas as recorrentes justificativas parlamentares para demandar aumento dos próprios salários, fundadas no argumento dos enormes custos da atividade política ${ }^{46}$.

Dentre os 18 políticos dos quais foi possível calcular a variação patrimonial entre os anos de 1998 e 2006, é possível extrair uma média de $305 \%$. Porém, como toda média absorve também os menores índices, assim como os negativos, é preciso destacar que entre esses deputados dois deles realizaram a façanha de aumentar seu patrimônio para além dos três dígitos: 2 005,61\% e $1234,10 \%$. Com a mesma competência, um ex-governador aumentou seu patrimônio em 2 $123,69 \%$ no curto espaço de 10 anos.

A análise mais minuciosa das Declarações, entretanto, permite perceber que alguns dos índices de variação patrimonial negativa ou reduzida apresentam algumas peculiaridades: 1) há declarações que não apresentam valores, mas apenas a discriminação do bem; 2) há declarações que, comparadas, apresentam depreciações que correspondem a quase um terço do valor inicialmente declarado; 3) terrenos urbanos - especialmente no interior do estado - são avaliados em

46 Não farei aqui, sequer, a relação necessária entre os salários dos parlamentares e o salário mínimo vigente no país e sua fragrante inconstitucionalidade. De acordo com Dieese (Departamento Intersindical de Estatísticas e Estudos Socioeconômicos), o salário mínimo necessário para cumprir os preceitos constitucionais deveria ser de $\mathrm{R} \$ 2$ 072,70, em junho de 2008. valores absolutamente irrisórios. Alguns chegam a apresentar valor igual a $\mathrm{R} \$ 1$; 4) bens localizados em Cuiabá, em bairros considerados de classe média alta, aparecem com valor subavaliado ou, simplesmente, sem referência de valor.

Por fim, importa registrar o saldo em conta corrente declarado por um Deputado: $\mathrm{R} \$$ 1.730.000,00, o que representou um aumento patrimonial - nada desprezível - de 525,33\% no curto espaço de quatro anos.

Vê-se, assim, que várias são as formas por meio das quais os agentes públicos passam a viver da política e fazem dessa condição um conveniente mecanismo de ascensão social e patrimonial.

Conseqüentemente, o pressuposto weberiano de que aqueles que têm recursos materiais podem viver para a política não encontra ressonância nos dados pesquisados. Em primeiro lugar, porque a política institucional passa a constituir-se em fonte de renda, mas também porque a participação direta nas esferas decisórias - seja no poder Legislativo seja no poder Executivo - permite a utilização de competências administrativas ou legislativas para estabelecer benefícios que alcançam atividades econômicas e relações de compadrio social e/ou familiar.

Em segundo lugar, porque se a permanência na atividade política institucional ao longo de vários anos (permitindo a profissionalização), não assegurasse ascensão econômica e social, estaríamos diante de uma situação no mínimo inusitada: o afastamento direto da atividade profissional de origem não compromete a estupenda acumulação patrimonial, o que significaria pôr por terra toda lógica econômica liberal que sustenta o modo de produção capitalista.

\section{CONCLUSÕES}

Considerado um "mal necessário" para os liberais e um "elefante branco perdulário e ineficiente" para os neoliberais, o Estado é, na verdade, a noiva sempre em disputa, e cuja conquista transforma-se em um pródigo casamento... para poucos. Como, entretanto, o Estado é o espaço político por excelência e para o qual convergem as disputas sociais, o grande desafio dos cônjuges é manter alienados aqueles que, por ventura, possam ameaçar a estabilidade da relação, comprometendo os ganhos privados a partir da ocupação dos espaços públicos. 
Ao investigar o perfil do poder Legislativo da capital e do estado de Mato Grosso, ao longo de mais de 20 anos, foi possível observar o quanto a negação do Estado - presente na maioria dos discursos partidários e eleitorais - não encontra guarita na prática dos parlamentares. O empenho em manter-se à frente dos espaços estatais decisórios - seja no poder Legislativo seja no poder Executivo - revela justamente o contrário.

Alienados da participação mais efetiva das práticas políticas institucionais, os cidadãos-eleitores somente acompanham (quando muito) a chamada "política pequena". E, hipnotizados pelas disputas por micro-poderes, os eleitores deixam passar incólumes a reprodução das práticas que condenam e que, estupefatos, na maioria das vezes, não compreendem. Tais práticas, entretanto, cumprem um importante papel de consolidar um sentimento social de desencantamento com a política institucional, assegurando, assim, a permanência no poder daqueles que fazem da política aquilo que a maioria dos eleitores condena.

A conseqüência desse processo eleitoralmente retroalimentado é a composição de parlamentos com pouca renovação parlamentar e com perfil partidário significativamente conservador. E, embora a condição profissional e sócio-econômica não seja garantia de renovação política e/ou compromisso social, não deixam de ser relevantes os percentuais de representação de trabalhadores assalariados ${ }^{47}$, assim como a ínfima representação de partidos social e efetivamente comprometidos com os interesses dos trabalhadores.

Em contraposição à sub-representação laboral, os empresários - articulados especialmente com os profissionais liberais - forjaram uma representação sólida, objetivamente unificada pelos projetos de sociedade que defendem (via partidos), mas que discursivamente negam.

Tem-se, assim, que boa parte dos parlamentares conseguiu construir uma base de sustentação institucional que se espraia para além dos espaços

47 De acordo com o portal Excelências (2009), do projeto Transparência Brasil, tanto a ALMT quanto a Câmara Municipal de Cuiabá não contam com representantes da chamada Bancada Sindicalista. Em compensação, há membros matogrossenses em todas as demais bancadas: ruralistas; concessão de rádio e/ou TV e evangélicos. eletivos, garante-lhes atuação política e dispõe-lhes parcelas não desprezíveis de poder. Afinal, se os percentuais de renovação aparentemente revelam superioridade sobre aqueles de recondução, tais índices não expõem as trajetórias institucionais que muitos parlamentares constroem de forma a aumentar seu capital eleitoral e, portanto, seus recursos de barganha intra e extra-partidária.

Ao consolidar os meios de manter-se na institucionalidade, seja via reeleição, pela disputa por outros cargos eletivos seja, ainda, via exercício de direção de secretarias e/ou demais órgãos públicos, esses parlamentares também vão tecendo os instrumentos legislativos que garantem a preservação e a ampliação de seus interesses particulares e de classe; como, aliás, bem identificou Claus Offe.

Conseqüentemente, ao passar a viver para a política - no sentido da profissionalização institucional - tais políticos passam, também, a viver da política. Como resultado, não somente ampliam significativamente seu patrimônio material como ainda vão loteando os espaços públicos e, dentro dessa mesma lógica, constroem seu patrimônio político, construindo uma rede particular e familiar de descendentes políticos que dão prosseguimento aos caminhos abertos por seus antecessores.

Assim, em linhas gerais, tanto parlamentares da Câmara de Cuiabá quanto da Assembléia Legislativa comungam uma mesma prática, de acordo com a qual a Casa Municipal funciona como um trampolim que abre os caminhos da profissionalização política.

Isso não significa, entretanto, que o perfil do poder Legislativo da Capital é, tão somente, a reprodução em menor escala daquele que se apresenta no Legislativo estadual. A Câmara Municipal configura-se percentualmente menos conservadora politicamente e mais aberta, proporcionalmente, ao ingresso de trabalhadores assalariados em relação aos empresários. Porém, dado o trânsito entre as casas, assim como a consolidação eleitoral de determinados partidos - em especial o PMDB, seguido pelo PFL, PTB e PSDB - o perfil de ambas as casas acaba convergindo para uma configuração muito próxima que permite caracterizá-las como política e socialmente conservadoras. 
Alair Silveira (alairsilveira@cpd.ufmt.br) é Mestre em Sociologia Política pela Universidade Federal de Santa Catarina e Professora da Universidade Federal de Mato Grosso.

BOBBIO, N. 1992. O futuro da democracia. Uma defesa das regras do jogo. $5^{\text {a }}$ ed. São Paulo : Paz e Terra.

CHACON, V. 1998. História dos Partidos Brasileiros : Discurso e práxis dos seus programas. $3^{\text {a }}$ ed. Brasília : UNB.

DALLARI, D. A. 1998. Elementos da Teoria Geral do Estado. $20^{\mathrm{a}}$ ed. São Paulo : Saraiva.

DA MATTA, R. 1983. Carnavais, Malandros e Heróis. Para uma sociologia do dilema brasileiro. $4^{\mathrm{a}}$ ed. Rio de Janeiro : J. Zahar.

DREIFUSS, R. A. A Internacional Capitalista. Estratégias e táticas do empresariado transnacional (1918-1986). 1987. $2^{\text {a }}$ ed. Rio de Janeiro : Espaço e Tempo.

FIGUEIREDO, A. C. \& LIMONGI, F. 1999. Executivo e Legislativo na nova ordem constitucional. Rio de Janeiro : FGV.

FLEISCHER, D. 2004. Os partidos políticos. In : AVELAR, L. \& CINTRA, A. O. (orgs.). Sistema Político Brasileiro: Uma Introdução. Rio de Janeiro-São Paulo : Adenauer-StifrungUnesp.

GRAMSCI, A. 1988. Maquiavel, a política e o Estado Moderno. 6. ${ }^{a}$ ed. Rio de Janeiro : Civilização Brasileira.

HOLANDA, S. B. 1997. Raizes do Brasil. São Paulo : Cia. das Letras.

LINDBLOM, C. E. 1980. O processo de decisão política. "Coleção de Política n. 33". Brasília : UNB.

LODOLA, G.; TRAINE, M.; BENAVIDES, J. C.; DE LA TORRE, C. \& KELLER, A. 2004. Neopopulismo na América Latina. "Cadernos Adenauer". Rio de Janeiro : Konrad Adenauer, Ano V, n. 2, ago.

MAINWARING, S.; MENEGHELLO, R. \& POWER, T. 2000. Partidos Conservadores no Brasil Contemporâneo. Quais são, o que de- fendem, quais são suas bases. São Paulo : Paz e Terra.

MAQUIAVEL, N. 1999. O Príncipe. "Os Pensadores". São Paulo : Nova Cultural.

MONTESQUIEU, C. L. S. 1985. Do espirito das

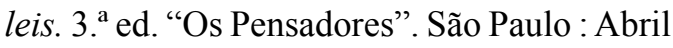
Cultural.

NEVES, M. M. R. N. 2001. Leões e raposas na política de Mato Grosso (até 1978). Rio de Janeiro : Mariela.

OFFE, C. 1984. Problemas estruturais do Estado Capitalista. Rio de Janeiro : Tempo Brasileiro.

ROUSSEAU, J-J. 1999. Do Contrato Social. São Paulo : Nova Cultural, v. I e II.

SILVEIRA, A. 2000. Caderno de Teoria Politica. Programa de Formação: Concepção Política e Sindical Sintep - Sec. XXI. Cuiabá : Make Up.

2002. Memória Social \& Processo Eleitoral. As motivações do voto em Cuiabá e Várzea Grande. Cuiabá : Entrelinhas.

(coord.). 2007. Relações de poder e representação de interesses entre setores empresariais e poder público, no estado de Mato Grosso e no município de Cuiabá, durante os anos 1985 e 2002. Cuiabá : UFMT. (Ministério da Educação, projeto 029/CAP/2007). Projeto em andamento.

SINGER, A. 2000. Esquerda e Direita no eleitorado brasileiro. A identificação ideológica nas disputas presidenciais de 1989 e 1994. São Paulo : EDUSP.

SOARES, G. A. D. 2001. A democracia interrompida. Rio de Janeiro : FGV.

WEBER, M. 1991. Economia e Sociedade. 5. ${ }^{\mathrm{a}}$ ed. Brasília : UNB.

1968. Ciência e Política. Duas vocações. 2. ${ }^{a}$ ed. São Paulo : Cultrix. 


\section{OUTRAS FONTES}

EXCELÊNCIAS. 2009. Sítio do projeto Excelências: parlamentares em exercício no país. Transparência Brasil. Disponível em : http:// www.excelencias.org.br/ Acesso em : 7.ago.2009.
Incentivos fiscais quase dobram no governo Lula. 2007. Folha de S. Paulo, 1.jul., p. B-1.

Lotacionograma do TCE expõe o nepotismo entre os Conselheiros. 2007. Mídia News, 26.mar.

\section{ANEXO}

\begin{tabular}{llll} 
PARTIDOS POLÍTICOS BRASILEIROS & & cional \\
Arena - & Aliança Renovadora Nacional & PRP - & Partido Republicano Progressista \\
PAN - & Partido dos Aposentados da Nação & PRTB - & $\begin{array}{l}\text { Partido Renovador Trabalhista Brasi- } \\
\text { leiro }\end{array}$ \\
PCB - & Partido Comunista Brasileiro & & Partido Socialista Brasileiro \\
PC do B - & Partido Comunista do Brasil & PSB - & Partido Social Cristão \\
PCO - & Partido da Causa Operária & PSC - & Paria \\
PDC - & Partido da Democracia Cristã & PSD - & Partido Social Democrático \\
PDS - & Partido Democrático Social & PSDB - & Partido da Social Democracia Brasilei- \\
PDT - & Partido Democrático Trabalhista & & ra \\
PFL - & Partido da Frente Liberal & PSDC - & Partido Social Democrata Cristão \\
PGT - & Partido Geral dos Trabalhadores & PSL - & Partido Social Liberal \\
PHS - & Partido Humanista da Solidariedade & PSOL - & Partido Socialismo e Liberdade \\
PL - & Partido Liberal & PST - & Partido Social Trabalhista \\
PMDB - & Partido do Movimento Democrático & PSTU - & Partido Socialista dos Trabalhadores \\
& Brasileiro & Unificado \\
PMN - & Partido da Mobilização Nacional & PT - & Partido dos Trabalhadores \\
PP - & Partido Popular / Partido Progressista & PTB - & Partido Trabalhista Brasileiro \\
PPB - & Partido Progressista Brasileiro & PTN - & Partido Trabalhista do Brasil \\
PPS - & Partido Popular Socialista & PV - & Partido Verde \\
PRN - & Partido da Reconstrução Nacional & UDN - & União Democrática Nacional \\
Prona - & Partido de Reedificação da Ordem Na- & & \\
& & & \\
\hline
\end{tabular}




\section{THE PROFILE OF LEGISLATIVE POWER IN THE CAPITAL AND THE STATE OF MATO GROSSO (1983-2004)}

\section{Alair Silveira}

This article is the result of research carried out in the two main legislative houses of the state of Mato Grosso: the Legislature (Assembléia Legislativa (ALMT)) - and the Municipal Chamber of Cuiabá (Câmara Municipal de Cuiabá (CMC)). Altogether, 20 years were covered in the ALMT and 22 in the CMC, totaling five legislative periods in each of the houses, as of 1983. It reflects on the profile of these parliaments through political party composition, professional background and the experiences of collective organizations, among others, identifying the enormous ability to perpetuate power on the part of members of the parliament, whether through the electoral process or through the management of state enterprises. Making particular use of the works of Claus Offe and Max Weber, we confront both Offe's premises, according to which entrepreneurs use power structures to promote valorization of capital, and Weber's. In the latter's view, those with a political vocation are those that live for politics and therefore, have the material resources that guarantee their independence, which is different from those who live from politics, in other words, those who depend upon politics for their survival. Analysis of research data enable us to identify strong elements that would corroborate the first premise, but cast doubt on the second. In consolidating the means to conserve institutional arrangements, whether by re-election, campaign for a new elected office or through exercising administrative positions within government organs, these members of parliament are putting together their legislative tools for the preservation and widening of their private and class interests, just as Claus Offe has identified. Thus, as they come to live for politics, they in turn also begin to live from politics.

Keywords: Legislative power; political parties; power; political renovation; Mato Grosso. 


\section{LE PROFIL DU POUVOIR LÉGISLATIF DE LA CAPITALE ET DE L'ÉTAT DE MATO GROS- SO (1938-2004)}

Alair Silveira

L'article est le produit d'une recherche menée dans les deux principales maisons législatives de l'état de Mato Grosso : l'assemblée législative (ALMT) et la chambre municipale de Cuiabá (CMC). Vingt années à l'AMLT et vingt-deux années à la CMC ont été étudiées, ce qui représente cinq législatures dans chacune des maisons, à partir de 1983. L'article examine le profil des parlamentaires de Mato Grosso et de Cuiabá à partir de la composition partidaire, des professions d'origine et de leurs expériences avec les organisations collectives, entre autres ; il identifie l'immense capacité de périnnisation au pouvoir de la part des parlamentaires, soit au moyen d'un processus électoral, soit au moyen de la direction d'entreprises publiques. En faisant appel à Claus Offe et à Max Weber, nous examinons aussi bien la prémisse d'Offe, selon laquelle les entrepreneurs ont recours à des structures de pouvoir pour promouvoir la valorisation du capital, que celle de Weber, selon laquelle les hommes politiques par vocation sont ceux qui vivent pour la politique et qui ont les moyens qui leur assurent l'autonomie donc, à l'opposé de ceux qui vivent de la politique, c'est-à-dire dont ils dépendent pour vivre. L'analyse des données de la recherche a permis d'identifier des élements importants qui renforcent la première prémisse, mais mettent en question la validité de la seconde. En assurant les moyens d'être dans l'arrangement institutionnel, soit via réélection, à travers la lutte pour d'autre postes, ou encore via la direction de secrétariats et/ou d'autres organismes publics, ces parlementaires construisent aussi les instruments législatifs qui assurent la préservation et l'amplification de leurs intérêts privés et de classe ; comme Claus Offe l'avait indiqué. Donc, en vivant pour la politique, ces politiques vivent aussi de la politique.

MOTS-CLÉS : pouvoir législatif ; partis politiques ; pouvoir ; rénovation politique ; réélection ; Mato Grosso. 